\title{
A STUDY OF THE SEROLOGICAL TYPES OF HAEMOLYTIC STREPTOCOCCI IN RELATION TO THE EPIDEMIOLOGY OF SCARLATINA AND OTHER INFECTIONS DUE TO THESE ORGANISMS
}

\author{
By H. L. De WAAL, M.D., D.P.H., D.T.M. AND H. \\ From the Department of Bacteriology, University of Edinburgh
}

(With 1 Figure in the Text)

CONTENTS

Records of scarlatinal cases examined

Monthly analysis of streptococcal types occurring in school children, their families and other persons

Predominance of individual types of haemolytic streptococei in certain schools . Types of haemolytic streptococci from diseases other than scarlatina .
A. Puerperal fever
B. Erysipelas
C. Otitis media and mastoiditis
D. Tonsillitis
E. Cases sent into a fever hospital as observation scarlatina

Types of haemolytic streptococci isolated from the throats of medical students .

Types of haemolytic streptococci in cases of tonsillitis, respiratory complaints, etc., during September 1938, occurring in a village community 12 miles from Edinburgh

Types of haemolytic streptococci isolated from the throats of nurses in a general hospital during an outbreak of sore throats

Types of haemolytic streptococci in the throats of nurses and medical officers in an infectious diseases hospital and other persons not suffering any complaints

(a) Nurses

(b) Medical officers in a fever hospital .

(c) Medical students

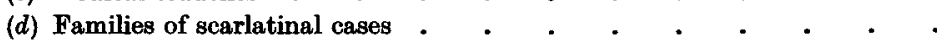

Rapid change of types of haemolytic streptococei in the nasopharynx of a person exposed to continuous heavy infection by this organism . $\quad . \quad$. $\quad . \quad$. 88

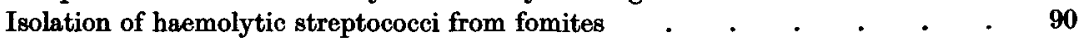

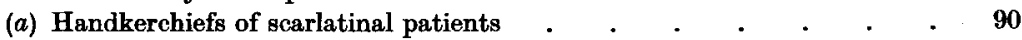

(b) Toys . . . . . . . . . . . . . . . . 9

(c) Food

Discussion .

Summary and conclusions

References

IN a previous paper the results were recorded of an inquiry into the occurrence of the various serological types of haemolytic streptococci in scarlatina with particular reference to the complications of the disease (de Waal, 1940). This inquiry has been extended with the object of obtaining by the same methods 
further information on the epidemiology of infections generally by haemolytic streptococci. The present communication is concerned mainly with these extended studies.

\section{RECORDS OF SCARLATINAL CASES EXAMINED}

During the sixteen-month period, 1 September 1937 to 31 December 1938, there occurred in Edinburgh 2287 cases of scarlatina, of which 2169 were treated in a fever hospital, and the remaining 118 at home. Of the 2287 cases 1364 were school children, and the other 923 adults or children under the age of five. The latter group has been divided into two categories: (1) 482 cases from families in which other members of school age also contracted scarlatina (called "Pupil-Contact Cases"), (2) 441 cases from families without children of school age (called "Non-Pupil-Contacts"); of these latter 263 were adults and 178 were children below the age of five.

Table 1 is a monthly record of the number of scarlatinal patients from the various schools and other institutions in Edinburgh, and from their families.

From this table it is seen that the highest incidence of scarlatina occurred during November 1937. After January 1938 the number fell rapidly and then remained at a fairly steady level until May, when another rise occurred. Thereafter a progressive fall in the number of cases took place till August 1938, when a slight increase occurred. November 1938 differed markedly from the same month of the previous year with regard to case incidence. (See Chart, p. 71.)

The epidemic during the winter months of 1937-38 was severe. It is interesting to note, however, that certain schools and other institutions practically escaped and only showed a rise in the number of cases during the spring or summer. (See school numbers: 5, 29, 41, 42, 43, 60, 80, 84, 109, 117, $121,124$.

Those schools which showed many cases during September-December 1937, relative to the total number of cases occurring in them during the period of investigation, showed correspondingly few cases during the same period of 1938. On the other hand, in schools in which the numbers were low in 1937 they were high in 1938, relative to the total number of cases. The first group is represented by four schools:

$\begin{array}{cccc}\text { No. of school } & \begin{array}{c}\text { Cases } \\ \text { during } \\ \text { Sept.-Dec. } \\ 1937\end{array} & \begin{array}{c}\text { Cases } \\ \text { during } \\ \text { Sept.-Dec. }\end{array} & \begin{array}{c}\text { Total no. } \\ \text { of cases } \\ \text { Sept. 1937- } \\ \text { Dec. 1938 }\end{array} \\ 25 & 44 & 1938 & 69 \\ 107 & 31 & 1 & 37 \\ 12 & 20 & 0 & 28 \\ 13 & 15 & 0 & 26\end{array}$

and the second group by three schools:

$\begin{array}{rrrr}52 & 15 & 7 & 53 \\ 111 & 9 & 10 & 30 \\ 27 & 7 & 5 & 28\end{array}$




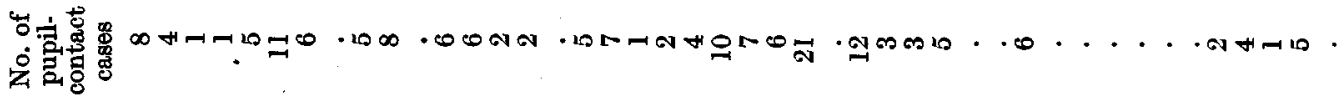

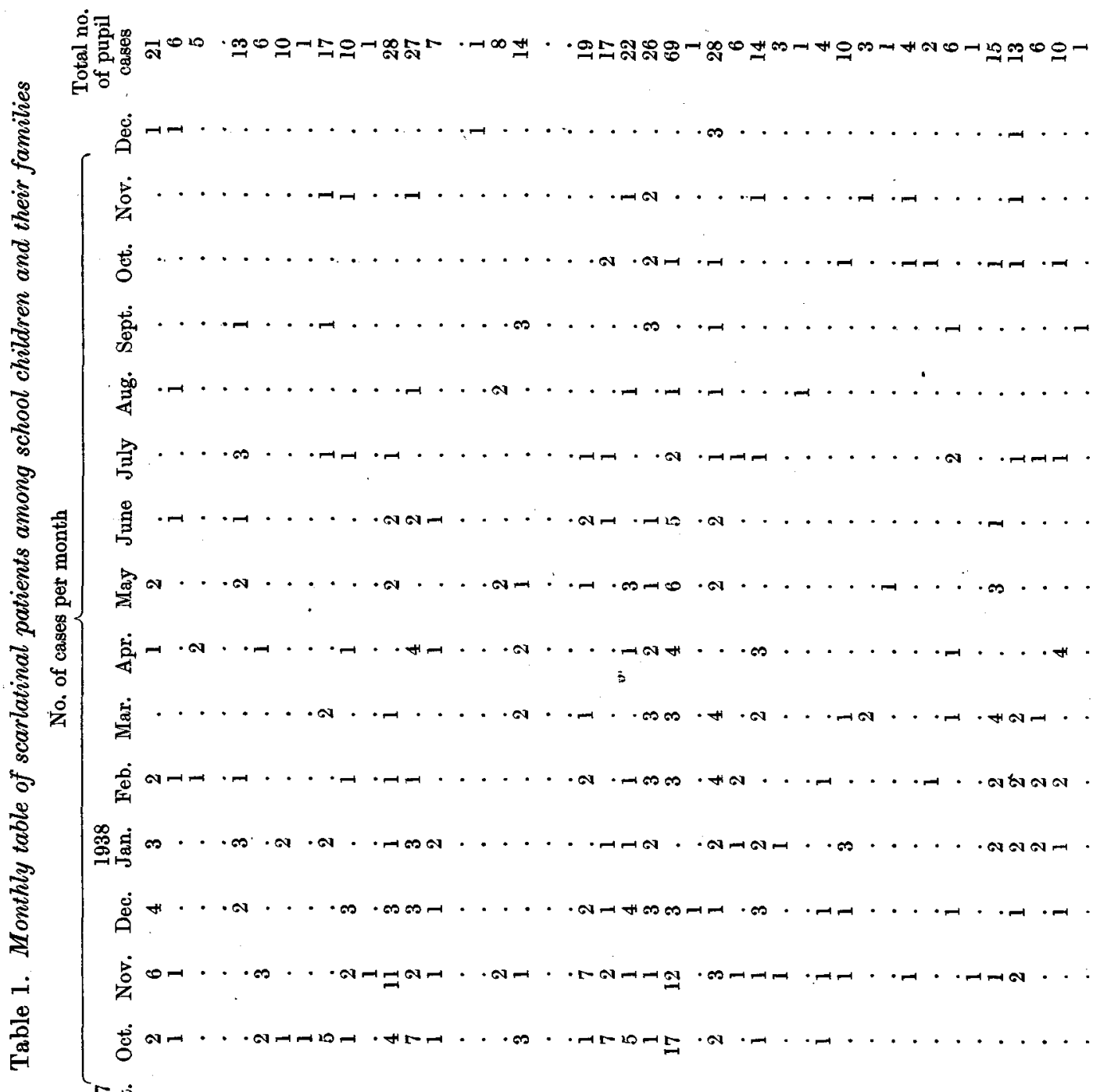

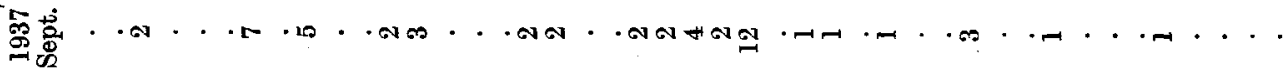

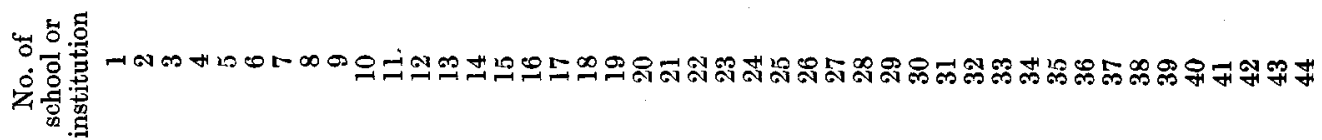




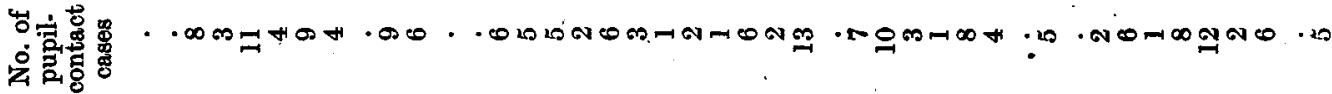

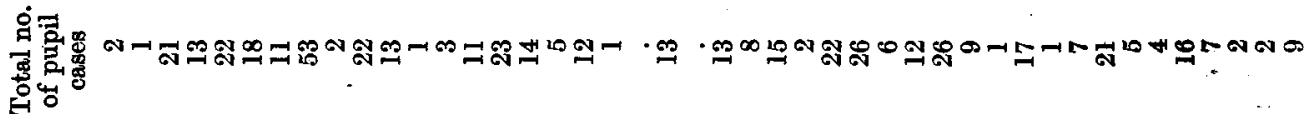

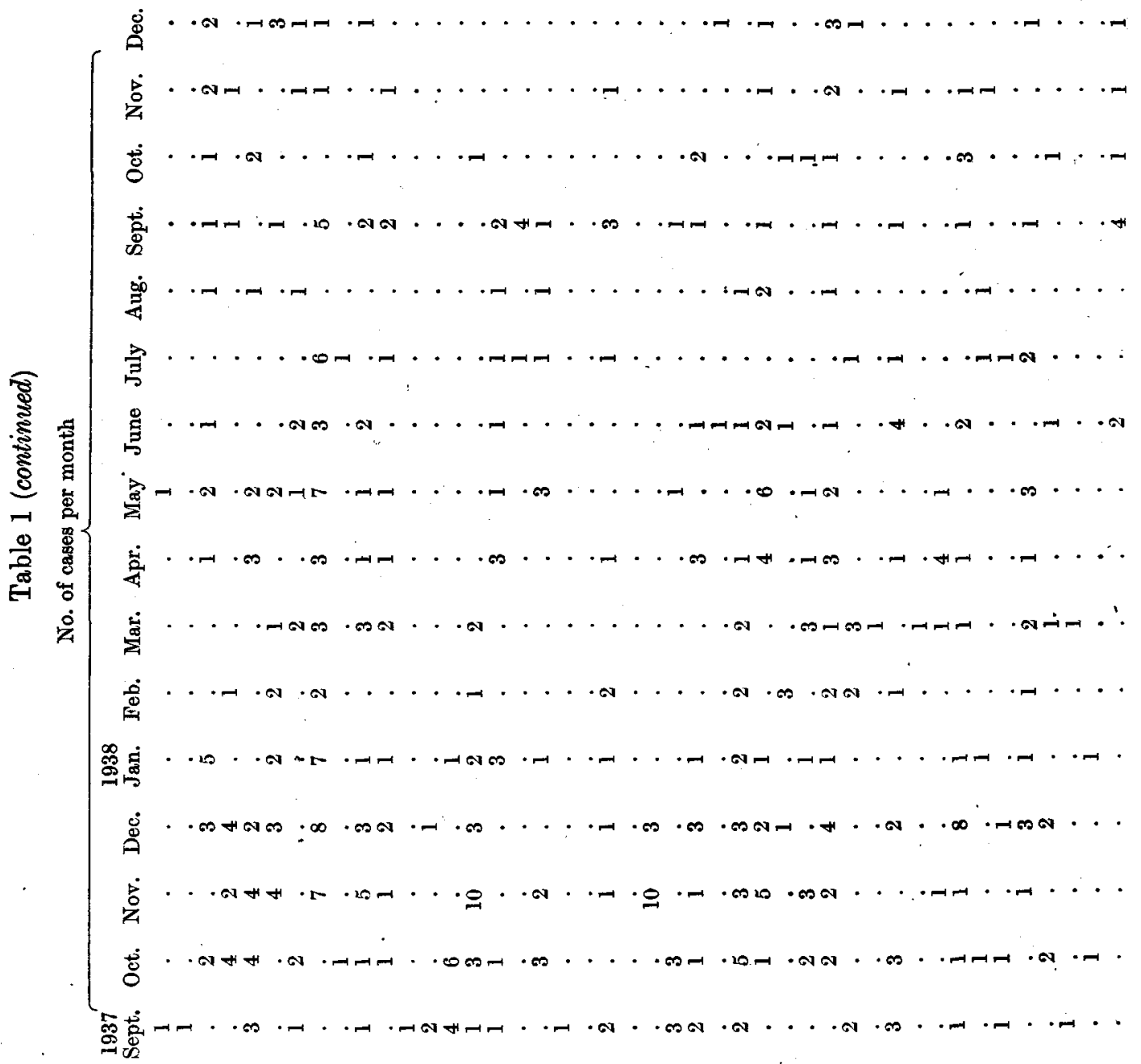
岁它迸 


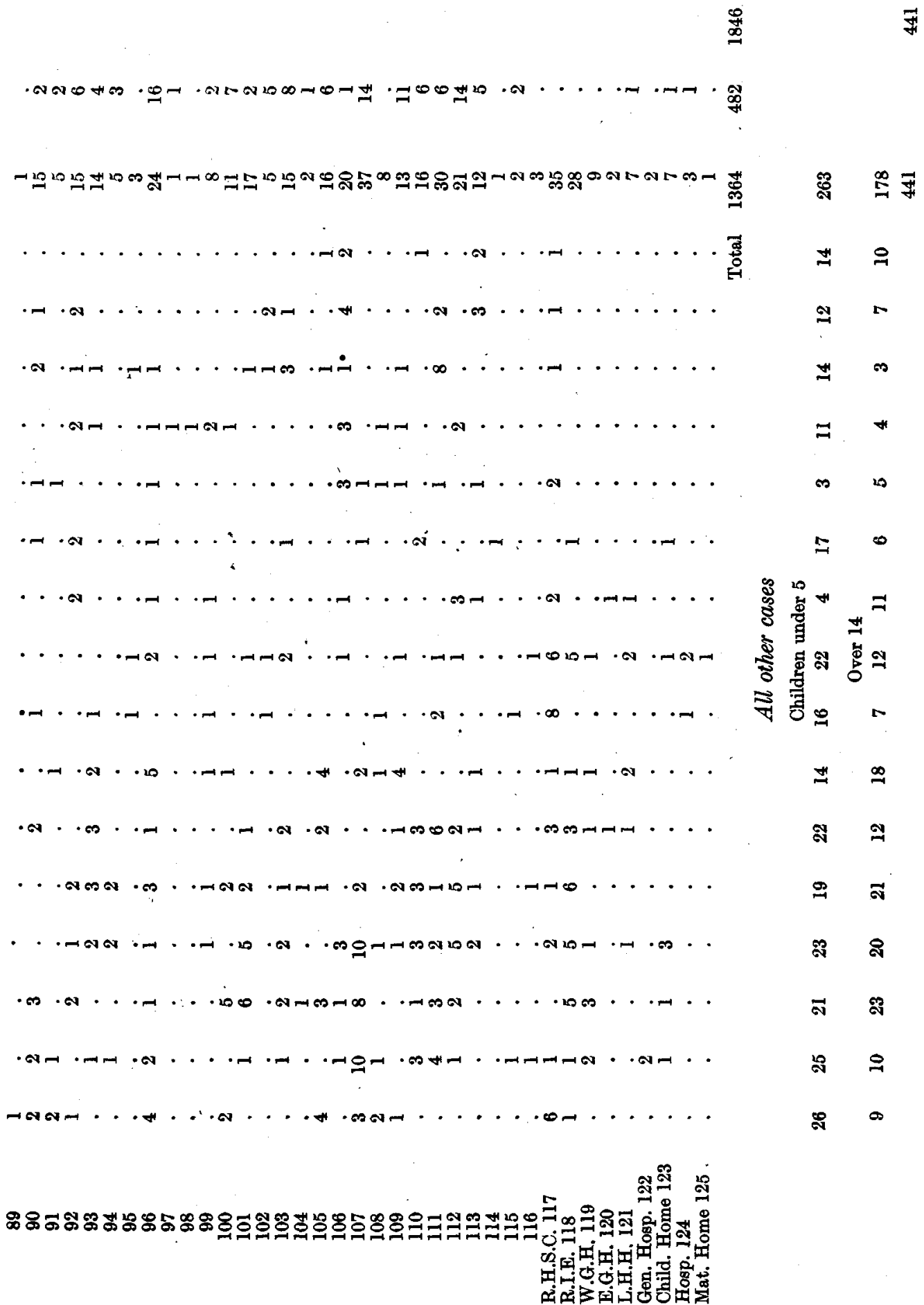


From the figures for the first group it appears that when, relative to the total number of cases over a long period, a large number of cases of scarlatina occur during a certain period in a school (viz. $44: 69,31: 37,20: 28,15: 26$ ), the number of cases occurring during the same period the following year will be low. The figures for the second group seem to indicate the converse; namely, that when the number of cases in a school, relative to the total number over a long period, is low during a certain period (viz. 15:53, $9: 30,7: 28$ ), a somewhat similar or greater number of cases may be expected the following year.

In Table 2 and Fig. 1 the number of scarlatinal cases occurring during each month in the whole community is given, school cases, "pupil-contact cases", and all other cases being shown separately.

Table 2. Showing the total number of scarlatina cases in each month

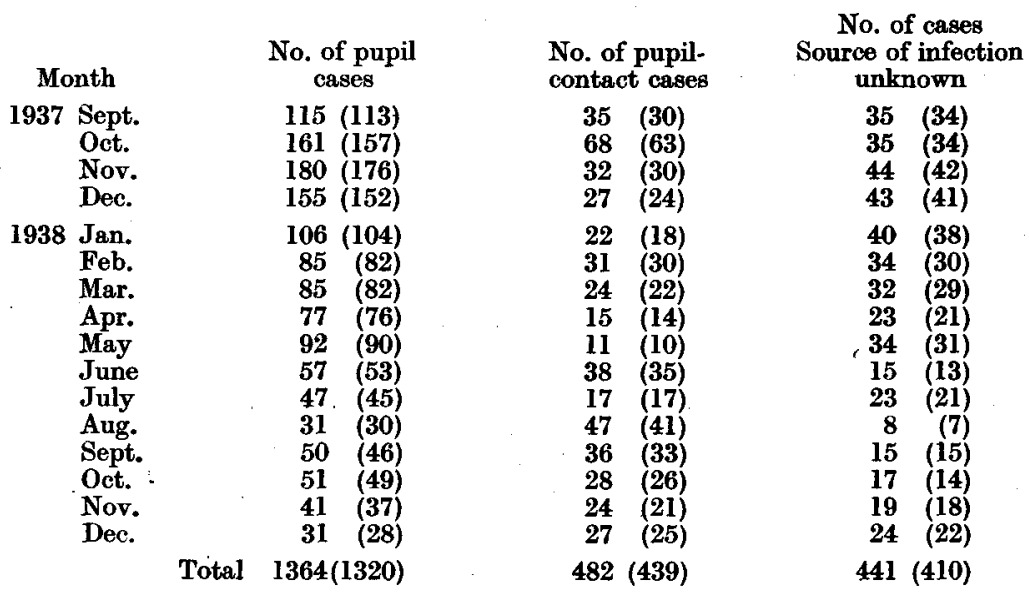

The figures in brackets indicate the numbers of cases treated in hospital.

The data given show that:

(1) During the height of the epidemic of scarlatina the majority of cases occurred in children of school age.

(2) The number of cases of scarlatina which occurred in "pupil-contacts" maintained a fairly steady level throughout the sixteen-month period, except during the height of the epidemic, when an increase was observed corresponding with the increase seen in the numbers of school cases.

(3) The number of cases (Fig. 1, $B$ ) which occurred in families who had no children at school did not increase to any extent during the epidemic of scarlet fever.

(4) The numbers of cases occurring in school children fell progressively after the epidemic without a similar decrease in the numbers from the rest of the community. This fall continued until more cases were seen among the 
"pupil-contacts" and "non-pupil-contacts" than among school children. (Fig. 1, $A$ and $B$; August and December 1938.)

(5) In Fig. 1 the lines indicating $(A)$ "pupil-contacts" and $(B)$ "non-pupilcontacts" are practically the reverse of each other. The explanation for this requires further investigation.

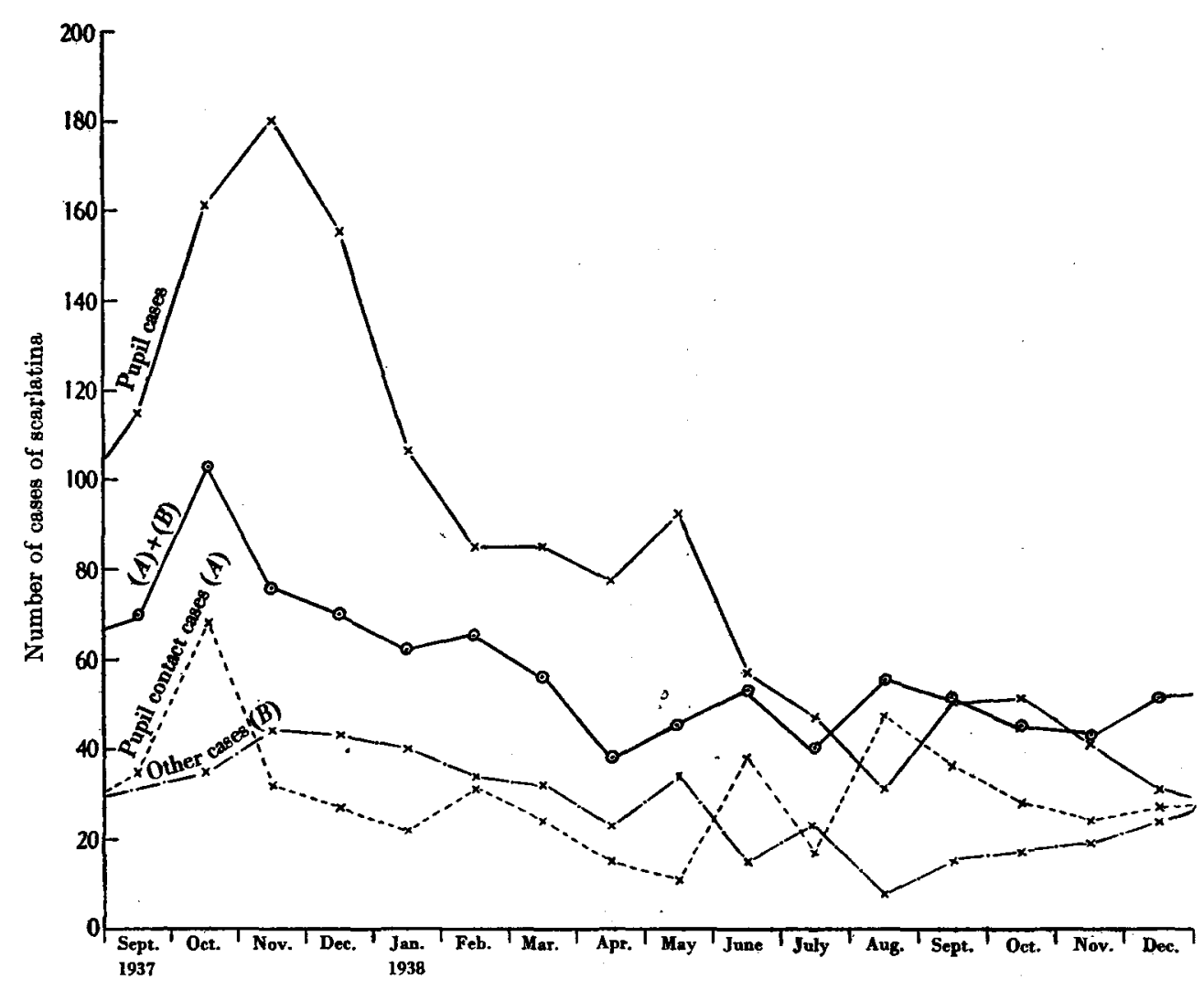

Fig. 1. Showing the number of cases of scarlatina occurring during each month in the whole community.

MONTHLY ANALYSIS OF STREPTOCOCCAL TYPES OCCURRING IN SCHOOL CHILDREN, THEIR FAMILIES AND OTHER PERSONS

Following this inquiry a monthly analysis of haemolytic streptococcal types occurring in the hospital-treated, cases of scarlatina was made. The technique employed was a modification of the slide-agglutination method of Griffith (1934), described in a previous communication (de Waal, 1940). The main findings are embodied in Table 3, which shows that:

(1) Certain types of haemolytic streptococei predominated in the school cases. These were types $2,4,8,11,15$. This feature is well illustrated in the figures for the months September-December 1937 and January-March 1938. 


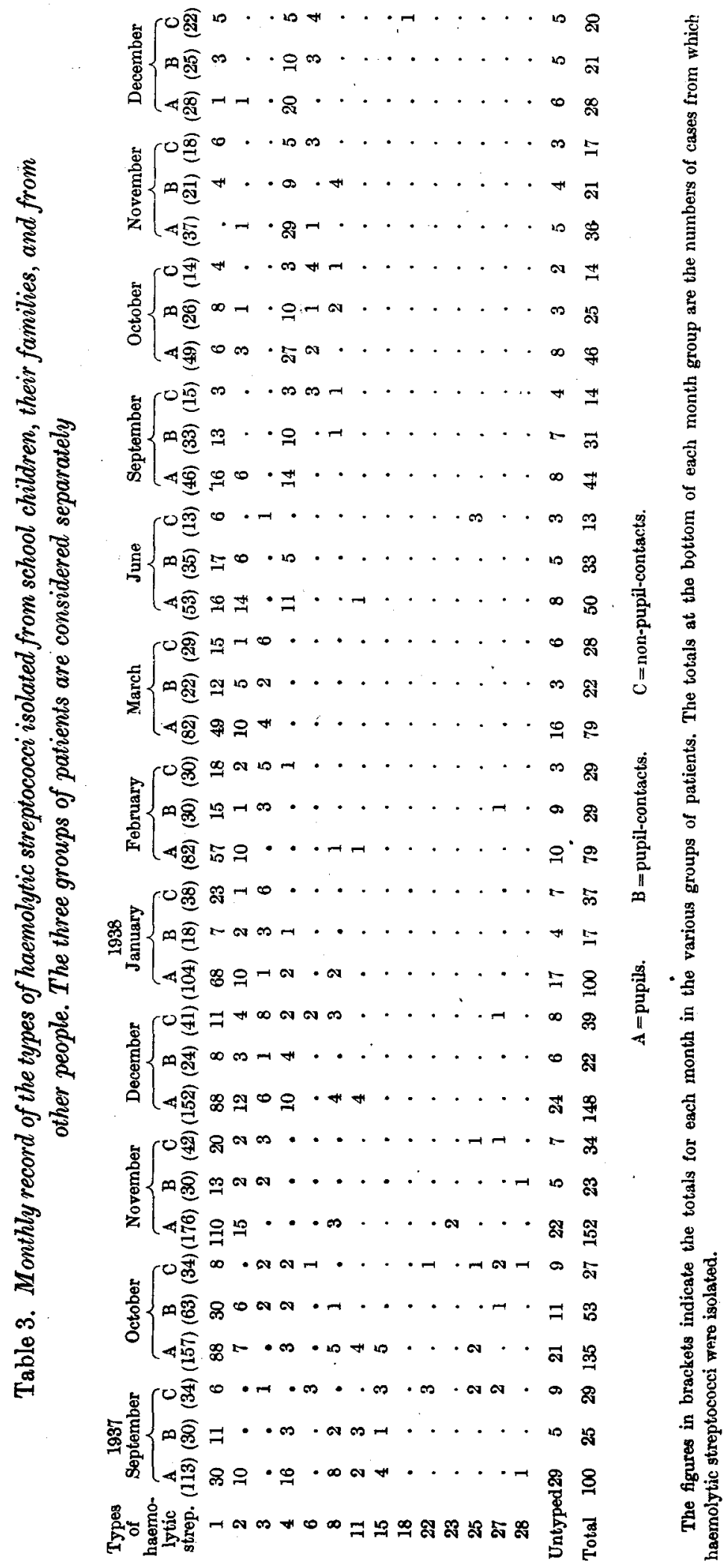


(2) The majority of new types of haemolytic streptococci, sporadic in their appearance, came from that group of patients classed as "Other Cases" (the source of infection here being unknown). This feature was particularly noticeable with regard to types $3,6,22,25,27$, during the months SeptemberDecember 1937.

(3) The types isolated from the cases coming from families with children of school age ("pupil-contact" cases) were related to those isolated both from pupil cases and "non-pupil-contact" cases, although their relationship to the types found in the last group was only slight. This was to be expected in a large community, for school children tend to infect one another; the parents and infant brothers and sisters of such children, in addition to their siblings above school age, are infected by these scholars, as well as by members of families without children of school age.

(4) Type 1 was fairly uniformly distributed among the three groups of patients during the first half of this inquiry, but later became replaced by type 4.

(5) Considering all the facts together it appears that during an epidemic of scarlatina one type of haemolytic streptococcus accounts for the majority of cases occurring in a community. The lesser types are sporadic in their appearance and tend to remain restricted to certain sections of the community.

According to the serological types of haemolytic streptococci isolated, scarlatinal cases may be roughly divided into three groups: one consisting of school children, another consisting of persons from families with no children of school age, and the third comprised of persons who come more in contact with both the former groups than they, do with each other (i.e. the families of school children).

\section{Predominance of Individual types of haemolytic streptococci IN CÉRTAIN SCHOOLS}

Table 4 shows that in certain schools particular types of haemolytic streptococci predominated, irrespective of whether they were the epidemic strains or not.

A number of interesting facts were observed:

(1) The majority of cases occurring in one school at a particular time were due to the same type of haemolytic streptococcus: e.g.

School no. 1 ... October (1937) to January (1938) ... Type 2.

School no. 9 ... September to October (1937) _.. Type 1.

School no. 33 ... September $\quad \ldots \quad \ldots . \quad \ldots \quad$... Type 4.

School no. 58 ... September to October $\quad \ldots \quad \ldots$ Type 15.

School no. 59 ... September (1937) to March (1938) ... Type 1.

School no. 96 ... September $\quad \ldots \quad \ldots . \quad \ldots \quad$... Type 4. 
Table 4. Showing the number of "typed" cases of scarlatina for each month in a selected number of schools

\begin{tabular}{|c|c|c|c|c|c|c|c|c|c|c|c|c|c|c|}
\hline \multirow{3}{*}{$\begin{array}{l}\text { Month. } \\
\text { School }\end{array}$} & \multicolumn{8}{|c|}{1937} & \multicolumn{6}{|c|}{1938} \\
\hline & \multicolumn{2}{|c|}{.September } & \multicolumn{2}{|c|}{ October } & \multicolumn{2}{|c|}{ November } & \multicolumn{2}{|c|}{ December } & \multicolumn{2}{|c|}{ January } & \multicolumn{2}{|c|}{ February } & \multicolumn{2}{|c|}{ March } \\
\hline & A & B & $\dot{A}$ & B & Á & B & $\dot{A}$ & B & Á & B & A & B & Á & B \\
\hline 1 & & & 2 & 2 & $\begin{array}{l}2 \\
1\end{array}$ & $\begin{array}{l}4 \\
1\end{array}$ & 2 & 2 & 2 & 3 & I & 2 & - & \\
\hline 9 & 1 & 4 & 1 & 5 & & & & & 2 & 1 & & & - & \\
\hline 12 & 1 & 2 & 1 & 4 & $\begin{array}{l}1 \\
8\end{array}$ & $\begin{array}{l}8 \\
\text { I }\end{array}$ & 8 & 2 & 8 & 1 & 1 & 1 & 1 & 1 \\
\hline 13 & $\begin{array}{l}1 \\
4\end{array}$ & $\begin{array}{l}2 \\
1\end{array}$ & $\begin{array}{l}1 \\
4\end{array}$ & $\begin{array}{l}\mathbf{4} \\
2\end{array}$ & I & 1 & I & $\mathbf{3}$ & 1 & 3 & $?$ & 1 & . & \\
\hline 25 & $\begin{array}{l}\text { l } \\
?\end{array}$ & $\frac{7}{5}$ & $\begin{array}{l}1 \\
?\end{array}$ & $\begin{array}{r}10 \\
7\end{array}$ & $\begin{array}{l}\text { I } \\
\text { ? }\end{array}$ & $\begin{array}{l}\text { I } \\
\mathbf{9}\end{array}$ & $?$ & 2 & & & 2 & 3 & 2 & $\mathbf{3}$ \\
\hline $33^{-}$ & 4 & 3 & & & 1 & 1 & & & 1 & 3 & & & 3 & 1 \\
\hline 47 & & & 25 & 2 & & & 1 & 2 & 1 & 5 & & & - & \\
\hline 52 & & & & & 2 & 6 & $\begin{array}{l}1 \\
2\end{array}$ & $\begin{array}{l}1 \\
6\end{array}$ & $\begin{array}{l}\mathbf{1} \\
\mathbf{2}\end{array}$ & $\begin{array}{l}5 \\
2\end{array}$ & 1 & 2 & 1 & 2 \\
\hline 54 & 8 & 1 & 8 & 1 & $\begin{array}{l}1 \\
8\end{array}$ & $\begin{array}{l}2 \\
2\end{array}$ & $\begin{array}{l}1 \\
8\end{array}$ & $\begin{array}{l}2 \\
\text { I }\end{array}$ & & & 1 & $\mathbf{3}$ & 1 & 1 \\
\hline 58 & 15 & 4 & 15 & 5 & & & & & 1 & 1 & & & - & \\
\hline 59 & I & 1 & 1 & 2 & 1 & 7 & 1 & 3 & 1 & 1 & 1 & 1 & 1 & 2 \\
\hline 71 & 11 & 2 & 11 & 4 & 1 & 3 & 1 & 2 & 1 & 2 & 1 & 1 & I & 1 \\
\hline 96 & 4 & 4 & $\begin{array}{l}1 \\
4\end{array}$ & $\begin{array}{l}1 \\
1\end{array}$ & & & 1 & 1 & 1 & 3 & $?$ & 1 & ? & $\begin{array}{l}\mathbf{1} \\
\mathbf{3}\end{array}$ \\
\hline 105 & 4 & 3 & & & 23 & 2 & & & 1 & 1 & $\mathbf{l}$ & 1 & l & 4 \\
\hline 107 & 1 & 2 & I & $\begin{array}{l}5 \\
3\end{array}$ & $\begin{array}{l}\text { I } \\
\text { ? }\end{array}$ & $\begin{array}{l}2 \\
6\end{array}$ & $\begin{array}{l}1 \\
?\end{array}$ & $\begin{array}{l}4 \\
3\end{array}$ & 1 & I & & & 1 & 2 \\
\hline 112 & & & 8 & 1 & 8 & 2 & 11 & 4 & $\begin{array}{l}1 \\
8\end{array}$ & $\begin{array}{l}2 \\
1\end{array}$ & $\begin{array}{l}1 \\
8\end{array}$ & $\begin{array}{l}1 \\
1\end{array}$ & - & \\
\hline
\end{tabular}

$A=$ Types of haemolytic streptococci. $\quad B=$ Number of cases for each type.

(2) The same types tended to persist in the same schools. Thus type 2 accounted for twelve of the thirteen cases which occurred in school no. 1, over a period of 4 months. Type 1 accounted for nine of the ten cases from school no. 9 during 2 months.

(3) In certain schools two types ran concurrently, but in the majority of such cases the one type disappeared and the other was isolated from most of the cases. This point is illustrated in school no. 54. Type 8 caused two cases during September and October. In November type 1 was introduced into the school and accounted for one case, whereas type 8 produced two more cases. The following month type 1 produced two cases and type 8 only one. After this type 8 disappeared and type 1 accounted for four other cases. School no. 52 also illustrates this point.

(4) School no. 58 is interesting in that the nine cases which occurred during September and October were due to type 15. It appears that all the susceptibles had contracted the disease, for no other case occurred till 3 months later, when a newly admitted pupil went down with scarlatina due to type 1 . 


\section{TYPES OF HAEMOLYTIC STREPTOCOCCI FROM DISEASES OTHER THAN SCARLATINA}

The types of haemolytic streptococci in conditions other than scarlatina are next considered. Scarlatina has been mentioned first since it is the most important of the haemolytic streptococcal infections from the numerical point of view. The types of the organism found in other conditions have been correlated with those found in scarlatina.

\section{A. Puerperal fever}

From October 1937 to November 1938 fifty-four cases of puerperal fever were investigated. Throat and cervical swabs were taken and in addition blood cultures were made in a few cases. Twenty-four of the cases were resident outside Edinburgh. A number of these had been delivered, however, in maternity homes within the city. It was therefore difficult to determine the source of infection of the last-mentioned group, and whether they formed part of the local epidemic of streptococcal infections, or whether they had brought the types with them from the country districts.

Of the fifty-four cases fourteèn gave swabs negative for haemolytic streptococci by ordinary blood-agar plate methods. All swabs were kept in the refrigerator for $24 \mathrm{hr}$. and those which at first were negative were again plated and cultured anaerobically. Two more swabs, both cervical, were shown to be positive. This left twelve cases which presumably had no haemolytic streptococci in their genital tracts or throats. Two of these swabs gave almost pure cultures of $B$. coli; one cervical swab yielded a heavy growth of $B$. pyocyaneus; and one showed a staphylococcoform organism which could not be classified. The forty-two cases which gave positive swabs may therefore be arranged as follows:

In twenty-two cases cervical swabs alone were positive.

In nine cases throat swabs alone were positive.

In seven cases both throat and cervical swabs were positive.

In two cases the blood cultures and cervical swabs were positive.

In one case the blood alone was positive.

In one case an incised breast (mastitis) gave a positive swab.

Only five blood cultures were made, the severest cases being chosen for this purpose. Of the five cases, four eventually died. In one case type 15 was found both in the blood and in the cervix, and in another case an untypable strain was obtained from both. Of the seven cases with positive throat and cervical swabs two had the same types in both regions, two cases gave untypable haemolytic streptococci from both areas and in three cases different types were found in the two swabs.

The findings in all these cases are given in Table 5. 
Table 5. Showing the types of haemolytic streptococci and other organisms isolated from puerperal fever cases

\begin{tabular}{|c|c|c|c|c|c|c|}
\hline \multirow[b]{2}{*}{ Case } & \multirow[b]{2}{*}{ Age } & \multirow{2}{*}{$\begin{array}{l}\text { Days in } \\
\text { hospital }\end{array}$} & \multicolumn{4}{|c|}{ Types of haemolytic streptococei isolated from } \\
\hline & & & Cervix & Throat & Blood & Breast \\
\hline 1 & 24 & 21 & 1 & 1 & . & . \\
\hline 2 & 42 & $\mathbf{3 3}$ & - & - & - & - \\
\hline 3 & 43 & Died & 4 & : & . & . \\
\hline 4 & 29 & Died & 3 & $\therefore$ & 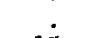 & . \\
\hline 5 & 29 & Died & 15 & . & 15 & . \\
\hline 6 & 30 & 19 & B. coli & . & . & . \\
\hline 7 & 33 & 23 & 1 & & . & . \\
\hline 8 & 27 & 18 & 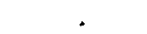 & 1 & . & . \\
\hline 9 & 24 & 39 & $?$ & . & . & . \\
\hline 10 & 21 & 48 & $?$ & & . & . \\
\hline 11 & 26 & 16 & 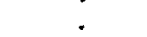 & 6 & . & . \\
\hline 12 & 38 & 24 & i & 2 & . & . \\
\hline 13 & 22 & 27 & $\cdot$ & 13 & . & : \\
\hline 14 & 25 & 27 & B. pyo. & & . & . \\
\hline 15 & 18 & 56 & 1 & ? & . & . \\
\hline 16 & 36 & 24 & $?$ & ${ }^{\circ}$ & . & . \\
\hline 17 & 37 & 14 & - & - & - & $\therefore$ \\
\hline 18 & 31 & 46 & 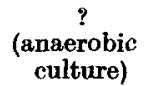 & . & . & . \\
\hline 19 & 28 & 21 & $=-$ & - & - & - \\
\hline 20 & 22 & 41 & - & - & - & - \\
\hline 21 & 24 & 4 & ? & & . & 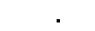 \\
\hline 22 & 19 & 14 & $?$ & ? & . & . \\
\hline 23 & 22 & 53 & ${ }^{*}$ & $\mathbf{3}$ & . & . \\
\hline 24 & 19 & Died & i & & . & . \\
\hline 25 & 35 & 28 & 13 & l & . & $\Rightarrow$. \\
\hline 26 & 42 & 15 & $?$ & . & . & \\
\hline 27 & 36 & 21 & $?$ & . & . & . \\
\hline 28 & 18 & 100 & 25 & . & . & . \\
\hline 29 & 18 & 18 & $?$ & . & . & $i$ \\
\hline 30 & 18 & 14 & 13 & . & . & : \\
\hline 31 & 34 & 1 & . & . & . & i \\
\hline 32 & 22 & 10 & . & $?$ & . & . \\
\hline 33 & 23 & 3 & - & - & - & - \\
\hline 34 & 28 & 11 & & 13 & . & . \\
\hline 35 & 18 & 14 & ? & . & . & . \\
\hline 36 & 31 & 40 & Staph. & . & . & . \\
\hline 37 & 25 & 21 & $?$ & . & . & . \\
\hline 38 & 32 & 20 & 28 & . & . & . \\
\hline 39 & 32 & 17 & - & - & - & - \\
\hline 40 & 25 & 35 & 28 & . & . & . \\
\hline 41 & 26 & 25 & 27 & . & . & $\because$ \\
\hline 42 & 19 & Died & ? & . & $?(\mathrm{Ar}$ & be) ? \\
\hline 43 & 24 & 21 & $?$ & - & & . \\
\hline 44 & 20 & 13 & - & - & - & - \\
\hline 45 & 37 & 35 & $?$ & ? & . & . \\
\hline 46 & 28 & 21 & . & $?$ & . & . \\
\hline 47 & 35 & 27 & - & - & - & - \\
\hline 48 & 22 & 33 & B. coli & . & . & . \\
\hline 49 & 29 & 26 & 6 & . & . & . \\
\hline 50 & 40 & 16 & $?$ & . & . & . \\
\hline 51 & 30 & 29 & & 4 & . & . \\
\hline 52 & 25 & 20 & 6 & . & . & . \\
\hline 53 & 32 & 35 & $?$ & . & . & . \\
\hline 54 & 22 & 23 & 4 & . & . & . \\
\hline
\end{tabular}


Of the typable strains of haemolytic streptococci from the puerperal fever cases examined type 13 was the only one not also present in the throats of scarlatinal cases. The numbers of cases in the two infections due to individual common types of haemolytic streptococci were related. Thus during October 1937 to January 1938 seven of the twenty-five strains belonged to type 1 . This period corresponded with the high incidence of type 1 in scarlatina (de Waal, 1940). After March type 1 no longer appeared in the puerperal fever cases examined. A further striking fact is the sudden outburst of type 4 in cases of puerperal fever in November 1938, at a time when an epidemic of scarlatina due to type 4 occurred (de Waal, 1940). Also there was the appearance in May 1938 of two puerperal fever cases due to type 28. May was the time when a sporadic increase of scarlatina took place due to type 28 associated with a serious increase in the number of complications. The appearance of type 6 in October 1938 likewise corresponded with a similar increase of that type in scarlatina.

In the puerperal fever cases examined a high percentage, twenty-two out of fifty types, of the number of haemolytic streptococci isolated could not be typed. In this respect the epidemiology of the condition differed markedly from that of scarlatina, where the percentage of typable strains was about 80 .

In order to appreciate better the correlations between the types of haemolytic streptococci found in scarlatinal cases and those isolated from other infections due to haemolytic streptococci reference should be made to de Waal (1940, Table 3, p. 178 and the Chart on p. 179).

\section{B. Erysipelas}

Early in the investigation swabs were taken only from those patients who showed broken skin over the erysipelatous lesions. This method was satisfactory in the cases in which the skin had recently broken down, but in those in whom the skin had broken down some time before the percentage of positive swabs obtained was very much lower. A more suitable method was therefore adopted. With an intradermal needle and hypodermic syringe a small bleb at the edge of the spreading margin of the lesion was punctured and the fluid aspirated. Where this could not be done a small amount of sterile saline was injected intracutaneously in the same region and then aspirated. The fluids obtained by these procedures were inoculated directly on to bloodagar plates and incubated. The results obtained were much more satisfactory, more positives being obtained and the number of contaminants greatly reduced.

From December 1937 to December 1938 forty cases of erysipelas were examined, with the results shown in Table 6.

(1) Only three of the forty cases failed to show the presence of haemolytic streptococci either in the throat or the lesion. 
Table 6. Showing the types of haemolytic streptococci present in the skin lesions and throats of cases suffering from erysipelas

\begin{tabular}{|c|c|c|c|c|}
\hline \multirow{2}{*}{$\begin{array}{l}\text { No. of } \\
\text { patient }\end{array}$} & \multirow[b]{2}{*}{ Age } & \multirow[b]{2}{*}{ Date } & \multicolumn{2}{|c|}{$\begin{array}{l}\text { Types of haemolytic } \\
\text { streptococci present in }\end{array}$} \\
\hline & & & Throat & Skin lesion \\
\hline I & 71 & 1937 Dec. & 1 & $?$ \\
\hline 2 & 34 & " & $\cdot$ & I \\
\hline 3 & 56 & 1938 Jä & & \\
\hline 4 & 10 & 1938 Jan. & 1 & 1 \\
\hline 5 & 53 & $"$ & - & 1 \\
\hline 6 & 53 & ", & $\dot{3}$ & 2 \\
\hline 7 & 23 & Fë & 3 & 3 \\
\hline 8 & 44 & Feb. & - & 1 \\
\hline 9 & 73 & $"$ & - & 25 \\
\hline 10 & 63 & & $\dot{x}$ & \\
\hline 11 & 46 & Mar. & 7 & 7 \\
\hline 12 & 4 & $"$ & i & i \\
\hline 13 & 57 & " & . & $\overline{2}$ \\
\hline 14 & 50 & ", & . & 7 \\
\hline 15 & 75 & " & $?$ & $30 ?$ \\
\hline 16 & 75 & 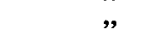 & . & $?$ \\
\hline 17 & 3 & Apr. & . & $\mathrm{i}$ \\
\hline 18 & 28 & May & & 7 \\
\hline 19 & 18 & $"$ & 1 & 1 \\
\hline 20 & 36 & $"$ & 28 & 28 \\
\hline 21 & 42 & $"$ & 1 & \\
\hline 22 & 48 & June & $?$ & $?$ \\
\hline 23 & 40 & ," & . & 25 \\
\hline 24 & 39 & 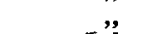 & . & 2 \\
\hline 25 & 41 & July & 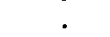 & 7 \\
\hline 26 & 31 & $"$ & $?$ & $?$ \\
\hline 27 & 49 & 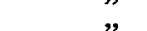 & $?$ & $?$ \\
\hline 28 & 15 & Aúg. & 4 & 4 \\
\hline 29 & $4 \frac{1}{2}$ & $"$ & 25 & 25 \\
\hline 30 & $42^{2}$ & $"$ & I & $?$ \\
\hline 31 & 61 & Sept. & 1 & $?$ \\
\hline 32 & 56 & 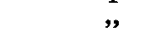 & . & 3 \\
\hline 33 & 18 & ", & . & 4 \\
\hline 34 & 52 & $"$ & . & 7 \\
\hline 35 & 38 & Oet. & . & $?$ \\
\hline 36 & 57 & $"$ & 4 & 4 \\
\hline 37 & 46 & $x "$ & & $?$ \\
\hline 38 & 42 & Nov. & 7 & 7 \\
\hline 39 & 47 & & & \\
\hline 40 & 63 & Dec. & 4 & 4 \\
\hline
\end{tabular}

(2) The types met with were: $1,2,3,4,7,25,28,30$.

(3) In three cases the throat swab gave a type different from that found in the lesion.

(4) In ten cases the throat harboured the same type as that found in the lesion.

(5) In four cases no haemolytic streptococci could be isolated from the lesions. In three of these the throat swabs were also-negative.

(6) During the period December 1937 to March 1938 five out of twelve cases were due to type 1. Type 4 appeared for the first time in October 1938. The second case due to this type occurred in December. This finding accords with the observations made in scarlatina and puerperal fever. One case due 
to type 28 occurred in May, the time when this type was responsible for the same two complaints.

(7) Type 7 was isolated from six patients. This type produced no cases of scarlatina.

(8) It is seen that of the seven cases below the age of twenty, not one carried type 7. With one exception (case 29) all these younger patients were infected with the common epidemic types 1 and 4. Only the older patients introduced the types 7, 25, 28.

(9) From this brief investigation it appears that in young patients the disease was caused by the common epidemic types of haemolytic streptococci, whilst in a large proportion of the older patients it was caused by non-epidemic types.

(10) Cases 11 and 37 are the same person. He was readmitted to hospital more than 7 months after his discharge, and on both occasions his erysipelas was due to type 7. Furthermore, he had this type in his throat on both occasions.

\section{Otitis media and mastoiditis}

Ten cases of otitis media with discharges were swabbed in the wards of the Ear, Nose and Throat Department of a general hospital, during September 1938. Six of the cases were children under the age of ten. Four were adults. The results are given in Table 7 .

\section{Table 7. Showing the types of haemolytic streptococci and other} organisms isolated from cases of otorrhoea associated with otitis media or mastoiditis

\begin{tabular}{|c|c|c|c|c|}
\hline \multirow[b]{2}{*}{ Case } & \multirow[b]{2}{*}{ Age } & \multirow[b]{2}{*}{ Complaint } & \multicolumn{2}{|c|}{ Organisms isolated from } \\
\hline & & & Ear & Throat \\
\hline 1 & 7 & Mastoiditis and otorrhoea & $\begin{array}{l}\text { Haemolytic strep., } \\
\text { type } 1\end{array}$ & . \\
\hline 2 & 10 & Mastoiditis and otorrhoea & $\begin{array}{l}\text { Haemolytic strep., } \\
\text { type } 4\end{array}$ & . \\
\hline 3 & $3 \frac{1}{2}$ & Otitis media and otorrhoea & $\begin{array}{l}\text { Haemolytic strep., } \\
\text { type } 4\end{array}$ & $\begin{array}{l}\text { Haemolytic strep., } \\
\text { type } 4\end{array}$ \\
\hline 4 & 20 & Otitis media and otorrhoea & $\begin{array}{l}\text { Haemolytic strep., } \\
\text { type } 14\end{array}$ & $\begin{array}{l}\text { Haemolytic strep., } \\
\text { type } 14\end{array}$ \\
\hline 5 & 6 & Otitis media and chronic otorrhoea & $\begin{array}{l}\text { Micrococcus tetra- } \\
\text { genus }\end{array}$ & \\
\hline 6 & 3 & Mastoiditis and otorrhoea & Str. viridans & Str. viridans \\
\hline 7 & 7 & Otitis media and otorrhoea & Str. viridans & Str. viridans \\
\hline 8 & 24 & Chronic otorrhoea and mastoiditis & S. albus & 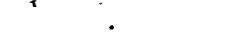 \\
\hline 9 & 27 & Otitis media and otorrhoea & S. aureus & S. aureus \\
\hline 10 & 42 & Otitis media and otorrhoea & Pneumococcus & \\
\hline
\end{tabular}

In only four cases were haemolytic streptococci found. Three were the epidemic types prevailing at the time and the other type 14. 


\section{Tonsillitis}

From January 1938 to March 1939 sixty cases of tonsillitis were investigated. An attempt was made, as far as was possible, to examine only cases likely to be of haemolytic streptococcal origin (viz. scarlatinal contacts, nurses, patients in fever hospital wards, etc.). Haemolytic streptococci were isolated in forty of the sixty cases. The results of typing are given in Table 8.

Table 8. Showing the types of haemolytic streptococci found in cases

\begin{tabular}{|c|c|}
\hline $\begin{array}{l}\text { No. of } \\
\text { patient }\end{array}$ & Age \\
\hline 1 & 16 \\
\hline 2 & 18 \\
\hline 3 & 61 \\
\hline 4 & 4 \\
\hline 5 & 12 \\
\hline 6 & 23 \\
\hline 7 & 17 \\
\hline 8 & 15 \\
\hline 9 & 7 \\
\hline 10 & 50 \\
\hline 11 & 3 \\
\hline 12 & 5 \\
\hline 13 & $2 \frac{1}{2}$ \\
\hline 14 & 41 \\
\hline 15 & 5 \\
\hline 16 & 3 \\
\hline 17 & 15 \\
\hline 18 & 8 \\
\hline 19 & 5 \\
\hline 20 & 14 \\
\hline 21 & 1 \\
\hline 22 & 10 \\
\hline 23 & 6 \\
\hline 24 & 6 \\
\hline 25 & 7 \\
\hline 26 & 9 \\
\hline 27 & 4 \\
\hline 28 & 8 \\
\hline 29 & 9 \\
\hline 30 & 2 \\
\hline 31 & 7 \\
\hline 32 & 3 \\
\hline 33 & 25 \\
\hline 34 & 1 \\
\hline 35 & 7 \\
\hline 36 & 6 \\
\hline 37 & 6 \\
\hline 38 & 3 \\
\hline 39 & 10 \\
\hline 40 & $1 \frac{1}{2}$ \\
\hline
\end{tabular}

\section{of tonsillitis}

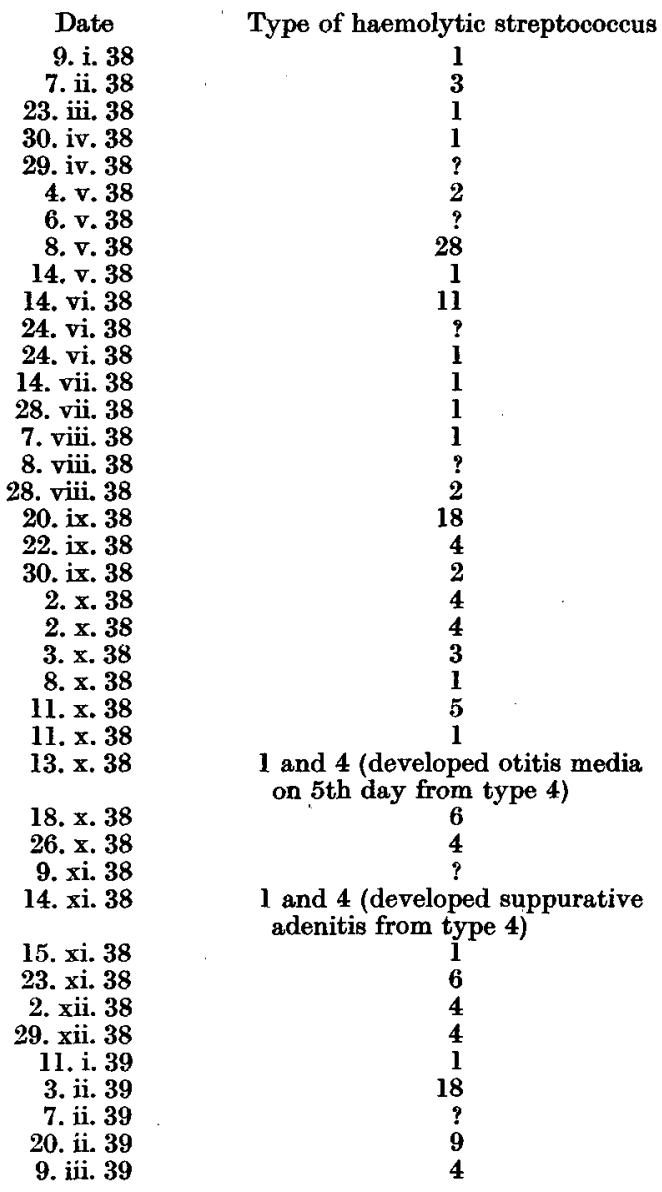

It is seen that a large number of types of haemolytic streptococci were responsible for tonsillitis. In this inquiry type 1 accounted for fourteen cases, type 2 for three cases, type 3 for two cases, type 4 for seven cases and two complications, type 5 for one case, type 6 for two cases, type 9 for one case, type 11 for one case, type 18 for two cases, type 28 for one case and untypable haemolytic for six cases. 
Types 1 and 4 predominated and bore the same relationship to each other as in scarlatina, namely, type 1 predominated in the early part of 1938 and type 4 during the later end. Two cases developed complications with type 4; the original type in both cases being 1 . The low complication rate of $5 \%$ stands in marked contrast to the high complication rate of $28.7 \%$ in scarlatina during the same period. The fact that most of the cases of tonsillitis were isolated would help to explain this low complication rate, for it was shown in a previous investigation (de Waal, 1940) that over $60 \%$ of complications in scarlatina were due to cross-infection with new types of haemolytic streptococci.

\section{E. Cases sent into a fever hospital as observation scarlatina}

The following observations were made on cases sent into a fever hospital as scarlatina or observation scarlatina by general practitioners and admitted to the isolation cubicles.

In all, sixty-three cases were examined; from twelve of these haemolytic streptococci were isolated, and only these have been recorded here.

Table 9. Indicating the types of haemolytic streptococci isolated from cases other than scarlatina though sent into hospital as such or as observation scarlatina

(In all cases except where otherwise stated the streptococci were isolated from the throat.)

\begin{tabular}{|c|c|c|}
\hline $\begin{array}{l}\text { No. of } \\
\text { case }\end{array}$ & Age & Complaint \\
\hline $\begin{array}{l}1 \\
2\end{array}$ & $\begin{array}{r}8 \\
14\end{array}$ & $\begin{array}{l}\text { Erythema } \\
\text { Septicaemia and acute nephritis }\end{array}$ \\
\hline $\begin{array}{l}\mathbf{3} \\
\mathbf{4}\end{array}$ & $\begin{array}{r}18 \\
2\end{array}$ & $\begin{array}{l}\text { Acute rheumatism } \\
\text { Bronchopneumonia }\end{array}$ \\
\hline $\begin{array}{r}5 \\
6 \\
7 \\
8 \\
9 \\
10 \\
11 \\
12\end{array}$ & $\begin{array}{r}71 \\
7 \\
5 \\
1 \\
7 \\
36 \\
7 \\
21\end{array}$ & $\begin{array}{l}\text { Erythema } \\
\text { Acute bronchitis } \\
\text { Erythema infectiosa } \\
\text { Bronchopneumonia and empyema } \\
\text { Acute nephritis } \\
\text { Peritonsillar abscess } \\
\text { Erythema infectiosa } \\
\text { Erythema }\end{array}$ \\
\hline
\end{tabular}

\begin{tabular}{|c|c|c|}
\hline Admitted & $\begin{array}{l}\text { Days in } \\
\text { hospital }\end{array}$ & $\begin{array}{l}\text { Type of } \\
\text { haemolytic } \\
\text { strep. }\end{array}$ \\
\hline $\begin{array}{r}\text { 15. x. } 37 \\
19 . \text { i. } 38\end{array}$ & $\begin{array}{c}9 \\
1 \\
\text { Died }\end{array}$ & $\begin{array}{l}\text { Blood } \mathbf{2} \\
\text { Throat } 5 \\
\text { Urine } 5\end{array}$ \\
\hline $\begin{array}{r}\text { 8. ii. } 38 \\
\text { 19. ii. } 38\end{array}$ & $\begin{array}{c}\mathbf{3 7} \\
\mathbf{3 8} \\
\text { Died }\end{array}$ & $\begin{array}{r}18 \\
4\end{array}$ \\
\hline 31. iii. 38 & 15 & 1 \\
\hline 26. iv. 38 & 7 & 13 \\
\hline 31. จ. 38 & 8 & 28 \\
\hline 1. vii. 38 & 54 & \\
\hline 15. ix, 38 & 51 & \\
\hline 23. x. 38 & 11 & \\
\hline $28 . x .38$ & 15 & \\
\hline 12. xii. 38 & 9 & 1 \\
\hline
\end{tabular}

Seven of these cases were due to the common epidemic types: $1,2,3,4$. Type 28 produced many streptococcal infections during May 1938, and may thus be regarded as one of the sporadic epidemic types.

\section{TYPES OF HAEMOLYTIC STREPTOCOCCI ISOLATED FROM THE THROATS OF MEDICAL STUDENTS}

The throats of eighty medical students were swabbed during November 1938. At the time there was an epidemic of sore throats and "colds". Eight swabs yielded haemolytic streptococci. These were placed in Lancefield's group A. Griffith's typing gave the following results: 
Table 10. Showing the types of haemolytic streptococci isolated from the throats of medical students during an epidemic of respiratory complaints

\begin{tabular}{clc} 
No. of atudent & \multicolumn{1}{c}{ Symptoms } & $\begin{array}{r}\text { Type of } \\
\text { baomnolytic } \\
\text { strep. }\end{array}$ \\
1 & None & 1 \\
2 & Slight tonsillitis & \\
3 & Slight tracheitis and cough & 1 \\
4 & Inflamed fauces & 4 \\
5 & None & $?$ \\
6 & Feeling feverish & 3 \\
7 & None & 25 \\
8 & Recovering from severe "cold" & 4
\end{tabular}

During November 1938 the epidemic types of haemolytic streptococi in scarlatina were 1 and 4 . Four of the eight students referred to in Table 11 had these types in their throats. The severest symptoms were produced by type 4. This conforms with the finding that type 4 produced the severer types of scarlatina and accounted for an extremely high percentage of the complications.'

It may be observed that in London the findings so far are different. Griffith (1934), Cooke \& Neisser (1937), and Neisser (1939) mention that type 4 is responsible for a mild form of scarlatina with a low complication rate, while the reverse is observed with cases due to type 1 . The cases due to type 1 in Edinburgh during 1937-38 were on the whole milder than those due to type 4, though the complication rate in the former was higher, frequently as the result of type 4 cross-infection. From analogy with other organisms it appears that haemolytic streptococci may become increasingly virulent or avirulent, depending upon factors as yet imperfectly understood.

TYPES OF HAEMOLYTIC STREPTOCOCCI IN CASES OF TONBILLITIS, RRSPIRATORY complatnts, etc., DURING September 1938, occurbine in a village comMUNTTY 12 MILUS FROM EDINBURG

Thirty-two patients were swabbed. Thirteen of these had haemolytic streptococci in their throats and (or) noses. They were classified as shown in Table 11.

Type 1 accounted for two cases, type 3 for five cases, type 17 for one case, type 26 for two cases and untypable for three cases.

Since half the typable haemolytic streptococci were of type 3 , it appears that this was the main epidemic type in that country district during September 1938. The observation is interesting, for it suggests that at a point only 12 miles from Edinburgh an epidemic of infections with another type of haemolytic streptococcus occurred in a semi-closed community. During this month not a single one of the eighty-nine cases of scarlatina examined in Edinburgh was found to be due to type 3, most being due to type 4 . 
Table 11. Showing the types of haemolytic streptococci found in the respiratory passages of persons residing 12 miles from Edinburgh and suffering from various complaints

\begin{tabular}{clc}
$\begin{array}{c}\text { No. of } \\
\text { patient }\end{array}$ & \multicolumn{1}{c}{$\begin{array}{c}\text { Complaint } \\
\text { Type of } \\
\text { haemolytic } \\
\text { strep. }\end{array}$} \\
2 & Acute pharyngitis & $?$ \\
2 & Acute pharyngitis & $\mathbf{1}$ \\
3 & Bronchitis & 3 \\
4 & Acute laryngitis & 3 \\
5 & Tonsillitis & 3 \\
6 & "Influenzal cold" & 1 \\
7 & Quinsy & $?$ \\
8 & Coryza (?) & 26 \\
9 & Tracheitis & 3 \\
10 & Acute bronchitis & 3 \\
11 & Rheumatic fever & 17 \\
12 & Acute bronchitis & 26 \\
13 & Purulent rhinitis & $?$
\end{tabular}

TYPES OF HAEMOLYTIC STREPTOCOCCI ISOLATED FROM THE THROATS OF NURSES IN A GENERAL HOSPITAL DURING AN OUTBREAK OF SORE THROATS

During January and February 1939 a number of nurses and patients in a general hospital developed sore throats. From 19 January 1939 to 14 February 1939 eighty nurses were swabbed; in those cases which yielded negative swabs, second and sometimes third swabs were taken. Of the eighty nurses thirtythree, at some stage or another, yielded haemolytic streptococci. The types found in nineteen are shown in Table 12:

Table 12. Showing the types of haemolytic streptococci isolated from the throats of nurses in a general hospital during an outbreak of sore throats

$\begin{array}{cccc}\begin{array}{c}\text { No. of } \\ \text { nurse }\end{array} & \begin{array}{c}\text { Type of } \\ \text { haemolytic } \\ \text { strep. }\end{array} & \begin{array}{c}\text { No. of } \\ \text { nurse }\end{array} & \begin{array}{c}\text { Type of } \\ \text { haemolytic } \\ \text { strep. }\end{array} \\ 1 & 4 & 11 & ? \\ 2 & 7 & 12 & 27 \\ 3 & 7 & 13 & 7 \\ 4 & ? & 14 & ? \\ 5 & 28 & 15 & ? \\ 6 & 20 & 16 & 20 \\ 7 & 4 & 17 & 28 \\ 8 & 17 & 18 & ? \\ 9 & 20 & 19 & 12 \\ 10 & 20 & & \end{array}$

In the nurses of this general hospital were found a number of types of haemolytic streptococci not commonly present in the throats of nurses in a fever hospital (see p. 84). Only the two types 4 and 28 played a part in the epidemiology of scarlatina. During the time this inquiry was conducted type 4 was definitely the preponderating type in scarlatina. Whether it was the semi-isolated life of the nurses in the hospital that accounted for the low incidence of the types responsible for scarlatina at the time, or their noncontact with cases and carriers in the city, or whether immunological factors were involved, were matters not investigated. 
TYPes OF HAEMOLYTIC STREPTOCOCCI IN THE THROATS OF NURSES AND MEDICAL OFFICERS IN AN INFECTIOUS DISEASES HOSPITAL AND OTHER PERSONS NOT SUFFERING ANY COMPLAINTS

During the period this inquiry was being conducted on persons suffering from haemolytic streptococcal infections, the serological types of the haemolytic streptococci occurring in the throats of the following groups of healthy persons were also investigated: $(a)$ nurses working in an infectious diseases hospital, $(b)$ medical officers in the same hospital, $(c)$ medical students, and (d) families of scarlatinal patients.

\section{(a) Nurses}

Of the forty nurses swabbed during the two periods of the year seventeen showed the presence of haemolytic streptococci in their throats. They were:

$\begin{array}{lrrrrr}\text { Scarlatina nurses } & \ldots & \ldots & \ldots & \ldots & 7 \\ \text { Measles nurses } & \ldots & \ldots & \ldots & \ldots & 2 \\ \text { Puerperal fever and erysipelas nurses } & \ldots & 4 \\ \text { Diphtheria nurses } & \ldots & \ldots & \ldots & \ldots & 4\end{array}$

Table 13. Types of haemolytic streptococci isolated from the throats of nurses working in the various wards of a fever hospital

\begin{tabular}{|c|c|c|c|}
\hline $\begin{array}{l}\text { No. of } \\
\text { nurse }\end{array}$ & $\begin{array}{c}\text { Type of } \\
\text { haemolytic } \\
\text { strep. }\end{array}$ & $\begin{array}{l}\text { No. of } \\
\text { nurse }\end{array}$ & $\begin{array}{l}\text { Type of } \\
\text { haemolytic } \\
\text { strep. }\end{array}$ \\
\hline & ard & & ard \\
\hline
\end{tabular}

Dec. 1937

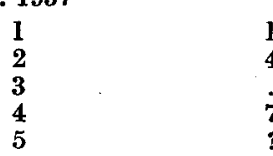

Feb. 1938

$4-12$

$\dot{7}=13$

13

15

May 1938

May 1938

$\begin{array}{rr}6 & 28 \\ 7 & 1 \\ 8 & \vdots \\ 9 & ?\end{array}$

No. positive 7

$\begin{array}{ll}16 & \text { i } \\ 17 & \text { : } \\ 18 & \text { : }\end{array}$

Puerperal and erysipelas ward

Feb. 1938

No. positive 2

Diphtheria ward

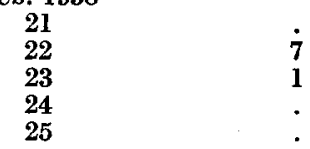

May 1938

26
27
28
29
30

No. positive 4

Feb. 1938

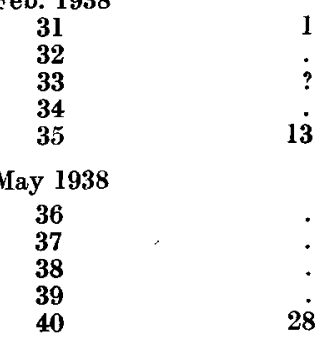

No. positive 4 
(1) Among those nurses most exposed to streptococcal infection the carrier rate was highest (viz. seven of the seventeen carriers were in the scarlatinal wards). The least number of carriers were found in the measles wards.

(2) It appears that nurses from one ward may carry haemolytic streptocci to those of other wards. Thus nurse 4, working in a scarlet-fever ward, had type 7 in her throat. This type occurred only in the erysipelas wards. Likewise in May 1938 nurse 40, working in a diphtheria ward, had type 28 in her throat. During this month there was an outbreak of complications among scarlatinal patients due to this type. The nurses of the various infectious diseases wards are segregated as far as possible, and how this cross-infection may occur by air contamination with haemolytic streptococci will be dealt with in a subsequent paper.

(3) The nurses were healthy carriers predominantly of the epidemic strains of haemolytic streptococci. Only one type, namely type 13, was not associated with streptococcal infections in the hospital at the time this investigation was carried out.

\section{(b) Medical officers in a fever hospital}

Table 14. Showing the types of haemolytic streptococci isolated from medical officers of an infectious diseases hospital

\begin{tabular}{|c|c|c|c|c|c|c|c|c|}
\hline \multirow{2}{*}{$\begin{array}{l}\text { Medical } \\
\text { officer }\end{array}$} & \multirow{2}{*}{$\begin{array}{l}\text { Patients } \\
\text { attended }\end{array}$} & \multicolumn{6}{|c|}{ Throat swabs at monthly intervals } & \multirow{2}{*}{$\begin{array}{c}\text { Types of } \\
\text { haemolytic } \\
\text { strep. }\end{array}$} \\
\hline & & i & 2 & $\mathbf{3}$ & 4 & 5 & 6 & \\
\hline $\mathbf{A}$ & Scarlatina & + & + &.+ & - & + & + & $1,1,2,1, ?$ \\
\hline B & Diphtheria & - & + & - & + & + & - & $7,4,1$ \\
\hline $\mathrm{C}$ & Measles and diphtheria & + & + & - & - & - & + & $22,1,4$ \\
\hline D & Tuberculosis & - & - & - & - & + & - & \\
\hline $\mathbf{E}$ & $\begin{array}{l}\text { Scarlatina, puerperal and } \\
\text { erysipelas }\end{array}$ & + & + & + & - & + & + & $1,7,7,1, ?$ \\
\hline $\mathbf{F}$ & $\begin{array}{l}\text { Scarlatina, diphtheria, } \\
\text { measles, puerperal and } \\
\text { erysipelas }\end{array}$ & - & - & + & + & + & + & $3,1, ?, ?$ \\
\hline
\end{tabular}

It may be observed that all the medical officers were healthy carriers of haemolytic streptococci at some period or other. These were, for the most part, the epidemic types, and were related to the types present in the wards at the various times. The most persistent carriers were the medical officers $A$ and $E$ (attending streptococcal infections). Medical officer $D$, in charge of patients suffering from tuberculosis, was the most sporadic carrier of the organism.

\section{(c) Medical students}

In the early autumn of 1938,190 medical students had their throats swabbed. At the time there was no marked epidemic of streptococcal infections. This organism was isolated in ten cases, and typed. 
Table 15. Types of haemolytic streptococci isolated from the throats of medical students

$\begin{array}{cc}\text { Student } & \begin{array}{c}\text { Type of } \\ \text { haemolytic } \\ \text { strep. }\end{array} \\ 1 & 20 \\ 2 & 17 \\ 3 & 1 \\ 4 & ? \\ 5 & 2 \\ 6 & ? \\ 7 & 2 \\ 8 & 1 \\ 9 & 20 \\ 10 & ?\end{array}$

Types 1 and 2 were those prevalent at the time in scarlet fever. Type 20, which occurred in two of the ten cases, was not isolated from any of the streptococcal cases examined during this investigation, but had been found in the throats of four of nineteen nurses in a general hospital (Table 13). Its pathogenicity therefore appears to be low.

\section{(d) Families of scarlatinal cases}

Sixteen families who had members in the scarlatina wards of a fever hospital were visited and all members swabbed. This was done with the view to determining whether there were carriers of haemolytic streptococi in such families, and if so, what relationship the types found bore to the patients in the hospital.

(a) L... family. Visited 21. x. 37 (two-apartment house).

\begin{tabular}{lccc}
\multicolumn{1}{c}{ Member of family } & Age & Throat swab & $\begin{array}{c}\text { haemolytic } \\
\text { strep. }\end{array}$ \\
Patient (Male, scholar, school 22) & 6 & Positive & 1 \\
Father (Labourer) & - & Negative & - \\
Mother & - & Negative & - \\
Brother (Scholar, school 22) & 10 & Negative & - \\
Brother (Page in picture house) & 14 & Positive & 25 \\
Brother & 3 & Negative & -
\end{tabular}

(b) B... family. Visited 3. xi. 37 (two-apartment house).

\begin{tabular}{lclc}
\multicolumn{1}{c}{ Member of family } & Age & Throat swab & $\begin{array}{c}\text { haemolytic } \\
\text { strep. }\end{array}$ \\
Patient (Female, scholar, school 22) & 8 & Positive & 1 \\
Father (Labourer) & - & Positive & 25 \\
Mother & - & Negative & - \\
Female lodger & 18 & Negative & - \\
Brother (Scholar, school 22) & 7 & Positive & 1 \\
Brother (Scholar, school 22) & 6 & Negative & - \\
Sister & 3 & Negative & - \\
Sister & $6 \frac{1}{2} \mathrm{~m}$. & Negative & -
\end{tabular}


(c) A... family. Visited 18. xi. 37 (three-apartment house).

\begin{tabular}{lccc}
\multicolumn{1}{c}{ Member of family } & Age & Throat swab & $\begin{array}{c}\text { haemolytic } \\
\text { strep. }\end{array}$ \\
Patient (Male, scholar, school 24) & 5 & Positive & 2 \\
Father (Labourer) & - & Negative & - \\
Mother & - & Positive & 2 \\
Sister (Scholar, school 24) & 7 & Positive & 2 \\
Baby & $9 \mathrm{~m}$ & Negative & -
\end{tabular}

The patient was admitted the day previous to the visit. This family was interesting. The sister, aged 7 years, had been in the fever hospital from 1 to 26 October 1937. Twenty-one days after she had left hospital the patient was sent to hospital and the same type with which the sister had originally entered the hospital was isolated from his throat. That the patient was a "return case" appears likely, since shortly after the sister resumed her schooling three cases of scarlatina occurred in her class, two of which were due to type 2. Whether she had infected her mother or whether the mother was the original carrier could not be ascertained with certainty, but the latter appears to be the case, for the mother gave a long history of throat infection.

(d) G... family. Visited 26. xi. 37 (three-apartment house).

\begin{tabular}{lccc}
\multicolumn{1}{c}{ Member of family } & Age & Throat swab & $\begin{array}{c}\text { haemolytic } \\
\text { strep. }\end{array}$ \\
Patient & 5 & Positive & $?$ \\
Father (Motor driver, at home) & - & Positive & 17 \\
Mother & - & Negative & - \\
Brother (Scholar, school 10) & 9 & Negative & - \\
Sister (Scholar, school 10) & 7 & Negative & - \\
Brother & 3 & Negative & -
\end{tabular}

The patient had entered hospital on 16 November 1937 with an untypable haemolytic streptococeus in his throat. The father was complaining of "rheumatism".

(e) A... family. Visited 2. xii. 37 (three-apartment house).

\section{Member of family}

Patient (Female, scholar, school 69)

Father (Basket maker)

Mother

Brother (Scholar, school 69)

Two sisters (Scholars, school 69)

Two babies

Female lodger

Female lodger

$\begin{array}{ccc}\text { Age } & \text { Throat swab } & \begin{array}{c}\text { haemolytic } \\ \text { strep. }\end{array} \\ 10 & \text { Positive } & 1 \\ - & \text { Positive } & ? \\ - & \text { Negative } & - \\ - & \text { Negative } & - \\ - & \text { Negative } & - \\ 2,3 & \text { Negative } & - \\ 18 & \text { Negative } & - \\ 24 & \text { Positive } & ?\end{array}$

The patient had entered hospital on 1 December 1937 and type 1 isolated from her throat. The female lodger of twenty-four was complaining of a sore throat. The type of haemolytic streptococcus found in her fauces could not be typed owing to the granularity of its growth. The streptococcus isolated from the father gave a similar culture. The house was hopelessly overcrowded and ventilation was inadequate. 
(f) S... family. Visited 20. iii. 38 (three-apartment house).

\begin{tabular}{lclc}
\multicolumn{1}{c}{ Member of family } & Age & Throat swab & $\begin{array}{c}\text { haemolytic } \\
\text { strep. }\end{array}$ \\
Patient (Female, scholar, school 25) & 5 & Positive & 2 \\
Father (Idle) & - & Negative & - \\
Female lodger & - & Negative & - \\
Brother (At home) & 6 & Negative & - \\
Sister (Scholar, school 114) & 11 & Positive & 2 \\
Brother (Scholar, school 25) & 9 & Negative & - \\
Twins (Kindergarten) & 3 & Negative & -
\end{tabular}

The patient had entered hospital on 18 March 1938 and type 2 was isolated. Two days before the patient's clinical symptoms became manifest the sister commenced complaining of tonsillitis. She was still suffering from this when the swab was taken. In her case type 2 was also found. Which patient infected the other could not be ascertained with certainty, but it appears that the one who contracted scarlatina infected her sister of eleven before she was sent to the fever hospital, for during the months of February and March six of the patients who entered hospital with type 2 had come from school no. 25 (the one attended by the patient). Furthermore, the sister of eleven was attending school no. 114, where no scarlatina occurred during this period.

(g) No haemolytic streptococci were isolated from any of the members of the other ten families visited.

In three of the six families recorded a definite relationship between the haemolytic streptococci in their throats and those from the scarlatina cases in the respective families existed. No such relationship could be found in the other three families.

\section{RAPID CHANGE OF TYPES OF HAEMOLYTIC STREPTOCOCCI IN THE NASOPHARYNX OF A PERSON EXPOSED TO CONTINUOUS HEAVY INFECTION BY THIS ORGANISM}

During a period when the writer was swabbing large numbers of cases of scarlatina every day it was a common experience to have many patients coughing over him. Furthermore, he spent a large part of the day in the wards. As a consequence he became heavily infected with haemolytic streptococci, as the following inquiry showed, and the opportunity was taken of making a detailed investigation of the carrier state.

The procedure was to take throat and nasal swabs every morning on arrival at the hospital before entering any of the wards, and to take two more swabs late in the day after frequent contact with scarlatinal patients.

(1) On thirteen occasions the same type of haemolytic streptococcus present after being in the wards was carried over to the next day in the throat or nose.

(2) On two occasions (8-9 January and 2-4 February) the types persisted in the throat for two and three days respectively. No symptoms were experienced. 
Table 16. Types of haemolytic streptococci in the throat and nose of a person before and after coming into contact with scarlet fever patients

\begin{tabular}{|c|c|c|c|c|}
\hline \multirow[b]{3}{*}{ Date } & \multicolumn{4}{|c|}{ Types of haemolytic strep. } \\
\hline & \multicolumn{2}{|c|}{ Before entering wards } & \multicolumn{2}{|c|}{ After entering wards } \\
\hline & Throat & Nose & Throat & Nose \\
\hline 1 Jan. & - & - & 8 & 8 \\
\hline & 8 & - & 8 & 1 \\
\hline 3 & - & 8 & 1 & 3 \\
\hline 4 & - & - & $?$ & 3 \\
\hline 5 & - & - & - & 8 \\
\hline 7 & - & -- & - & 4 \\
\hline 8 & 4 & 4 & 4 & 2 \\
\hline 9 & 4 & 4 & 4 & 4 \\
\hline 10 & - & - & - & 4 \\
\hline 11 & - & - & - & 2 \\
\hline 12 & 2 & - & 2 & - \\
\hline 14 & - & - & - & 1 \\
\hline 15 & 1 & - & 1 & 4 \\
\hline 16 & - & - & - & 8 \\
\hline 17 & - & 8 & - & 8 \\
\hline 18 & - & - & - & - \\
\hline 19 & 8 & - & 8 & 1 \\
\hline 21 & - & - & I & 1 \\
\hline 22 & - & - & - & - \\
\hline 23 & - & - & - & 8 \\
\hline 24 & 8 & - & 8 & 4 \\
\hline 25 & - & - & - & - \\
\hline 26 & - & - & - & $?$ \\
\hline 28 & - & - & - & 2 \\
\hline 29 & 2 & - & 2 & $\hat{\imath}$ \\
\hline 30 & - & - & I & $\hat{1}$ \\
\hline 31 & - & - & - & - \\
\hline 1 Feb. & - & - & - & $?$ \\
\hline 2 & $?$ & - & I & i \\
\hline 3 & $?$ & - & ? & ? \\
\hline 4 & $?$ & - & ? & $i$ \\
\hline 5 & - & - & - & - \\
\hline 6 & - & - & - & 1 \\
\hline 7 & 1 & - & 1 & ? \\
\hline 8 & - & - & - & 8 \\
\hline 9 & 8 & - & 1 & - \\
\hline
\end{tabular}

(3) On eighteen of the thirty-six occasions on which swabs were taken haemolytic streptococci were found in the throat; this contrasts with the twenty-nine occasions on which the organisms were present in the nose.

(4) On only four occasions were the nasal swabs positive before entering the wards.

(5) On ten of the twenty-nine occasions on which the streptococci were found in the nose or throat, after having been in contact with the scarlatinal cases, different types were isolated from the nose and throat.

(6) From this investigation it appears that a person who becomes heavily infected with haemolytic streptococci from scarlatina cases may harbour the organisms in the nasopharynx for periods varying from a few hours to some days (three in this case). Usually the infection does not last $24 \mathrm{hr}$.

(7) Immediately after contact with scarlatinal cases the nose is much more 
heavily infected than the throat. (It is possible that this state would be reversed if the investigator were a mouth-breather.)

(8) Since different types were isolated before and after entering the wards and also from the nose and throat after leaving the wards, it is probable that if large numbers of colonies had been typed from each swab culture more than two types would have been found at any particular time.

(9) A high degree of immunity probably arises from such frequent contact with haemolytic streptococci, and this may account for the short period any particular type remains in the upper respiratory tract.

It might have proved interesting if a comparative investigation had been carried out during the early stages of the research, when various symptoms of malaise, mild sore throat, low-grade pyrexia, etc. were experienced. With regard to the immunity acquired from such frequent contact with the organism it may be of some value to record that during September 1937 the writer infected his finger with type 11 . After about $8 \mathrm{hr}$., pain was experienced at the site of infection, and a lymphangitis set in. Intramuscular and oral doses of Prontosil were administered. For a period of $24 \mathrm{hr}$. there was a fever of 101$100 \cdot 2^{\circ} \mathrm{F}$. and a slight pain in the elbow and axilla. After 4 days this subsided and the temperature returned to normal. Twelve months later (August 1938), having taken about 6000 throat and nasal swabs in the interim, whilst preparing vaccines for rabbit immunization, a tube containing a heavy deposit of haemolytic streptococci isolated from a case of puerperal fever broke while being handled and some of the emulsion of living organisms entered a cut. Although the wound was only washed and dressed it healed within a few days without producing signs and symptoms.

\section{ISOLATION OF HAEMOLYTIC STREPTOCOCCI FROM FOMITES}

Finally, the types of haemolytic streptococci isolated from fomites, and the viability of the organisms, were investigated.

\section{(a) Handkerchiefs of scarlatinal patients}

Handkerchiefs were obtained from five patients on admission to hospital. Each handkerchief was cut into eight portions. One portion of each was well shaken up in a quantity of sterile saline. It was then removed and the fluid centrifuged at high speed. Some of the sediment was stroked out on a bloodagar plate. The seven remaining portions of each handkerchief were placed in a sterile wide-mouthed screw-capped bottle and the bottle closed. The bottles were kept in a corner of the ward out of the sun, as it was thought advisable not to remove them to the higher atmospheric temperature of the laboratory except when actual examination of the material was to be carried out. At weekly intervals a single portion of handkerchief was removed from each bottle with long sterile forceps and treated as before. The results obtained are given in Table 17. 
Table 17. Showing the types of haemolytic streptococci and the time of their survival on portions of handkerchiefs used by scarlatinal patients

\begin{tabular}{|c|c|c|c|c|c|c|}
\hline \multirow[b]{2}{*}{ Portion } & \multirow[b]{2}{*}{ Week } & \multicolumn{5}{|c|}{ Handkerchiefs } \\
\hline & & $\begin{array}{c}1 \\
\text { Type }\end{array}$ & $\begin{array}{c}2 \\
\text { Type }\end{array}$ & $\begin{array}{c}3 \\
\text { Type }\end{array}$ & $\begin{array}{c}4 \\
\text { Type }\end{array}$ & $\begin{array}{c}5 \\
\text { Type }\end{array}$ \\
\hline lst & lst & 1 & 1 & 2 & $?$ & 1 \\
\hline 2nd & 2nd & i & 1 & 2 & ? & 1 \\
\hline 3rd & $3 \mathrm{rd}$ & 1 & 1 & $\overline{2}$ & ? & 1 \\
\hline 4th & 4th & 1 & $\mathbf{1}$ & 2 & . & 1 \\
\hline 5th & 5 th & I & . & 2 & $\therefore$ & 1 \\
\hline 6th & 6 th & i & . & 2 & . & 1 \\
\hline 7th & 7 th & . & : & 2 & $\therefore$ & 1 \\
\hline 8th & 15th & . & . & . & . & . \\
\hline
\end{tabular}

After 3 weeks all the handkerchiefs still contained viable haemolytic streptococci. By the 7th week only two handkerchiefs showed the presence of these organisms, and none were found after 15 weeks. It must be pointed out that some of the handkerchiefs were moist to commence with and the maintenance of this moisture in the air-tight bottles may have affected the viability of the organisms.

\section{(b) Toys}

On 26 May 1938 a number of toys were selected for examination, namely three books, one celluloid doll and two wooden soldiers. Sterile swabs dipped in saline were carefully rubbed over the toys and then plated out. After incubation five of the six plates showed the presence of haemolytic streptococci. Only one was typed, that obtained from the doll. This article had been in possession of " $M$ ", aged $2 \frac{1}{2}$ years. It later fell from her cot and was picked up by a convalescent " $D$ " (aged 6 years), who played with it for some while before it was taken from her for this investigation. The type of haemolytic streptococcus that was present in "M's" throat was 25 , and the same type was isolated from the doll, whereas that in the throat of " $D$ " was 1 . The danger of cross-infection is obvious.

$$
\text { (c) Food }
$$

A half-eaten apple which was being shared by two convalescent youths was replaced by two whole apples and the part taken for investigation. On swabbing the surface of the eaten end and plating out, numerous haemolytic streptococci were isolated. They were not typed.

\section{Discussion}

The attack of haemolytic streptococci upon human health constitutes one of the main problems of medicine and public health. The treatment of infections by these organisms has undergone a revolution since the introduction of the sulphonamide group of drugs, but there still remains the problem of prophylaxis, which must depend in the first place on the fullest possible knowledge of the epidemiology of these infections. The object of the studies 
recorded in this paper has been to throw. light on some aspects of the epidemiology of streptococcal diseases by serological analysis of the organisms present.

Of the various streptococcal infections scarlatina has been chosen for the main inquiry, and the types found in this condition and in other streptococeal infections have been correlated as far as possible. The choice rested on the fact that the incidence of scarlatina is a good index of the extent of haemolyticstreptococcal infections present in a community, and also that this disease represents the greatest number of recognizable cases due to haemolytic streptococci.

The period over which the inquiry was conducted was particularly favourable, for it commenced during a severe epidemic of scarlatina and continued during its decline to interepidemic proportions. The following year was fortunately a non-epidemic one. The two periods thus afford a strong contrast.

In all 2287 cases of scarlatina occurred in Edinburgh during the sixteenmonth period, 1 September 1937 to 31 December 1938, and of these $94.8 \%$ were treated in an infectious diseases hospital. Roughly $60 \%$ of all the cases were school children. Since about $53 \%$ of these cases occurred during the first decade of life and nearly $70 \%$ during the first fourteen years, the well-known fact that scarlatina is essentially a juvenile complaint is again amply illustrated; furthermore, it is principally a disease of children gathered into close contact with each other in schools and institutions. This feature is not, however, alone responsible for the full trend of an epidemic, since it became evident that once a severe epidemic was established the intervention of a vacation had no marked effect upon the number of cases that occurred (e.g. during and following the Christmas vacation 1937 the case incidence still remained relatively high).

During the peak of the epidemic certain schools and institutions practically escaped, but in these there was more often than not a rise in the number of cases the following year, whereas no such definite increase was observed in those schools and institutions that had had many cases the previous season (see p. 66). The explanation for this may depend upon immunization by infection and subinfection unassociated with the scarlatinal syndrome, and the occurrence of scarlatina in most of the susceptibles, thus leaving few children to contract the disease the following year. In this connection Keogh and his collaborators (1939) have brought forward evidence that infection with one type of haemolytic streptococcus without the appearance of a rash may render persons immune to scarlatina from another type of the organism.

The greatest incidence during the epidemic of scarlatina occurred among school children. Conversely, once the epidemic began to decline, it was they 
who showed the greatest fall in numbers. No marked rise and fall occurred among other members of the community. Their case rate remained at a fairly steady level, whether there was an epidemic or not, except in the "pupilcontact" class, which showed a certain increase as the epidemic reached maximum proportions. The result of this was that during the inter-epidemic period the number of pupil cases was at certain periods less than those from other members of the community. From this it may be deduced that a marked fall in the case rate among school children is not by itself a true indication of the trend of an epidemic, but should be considered along with the total case rate for the whole community.

It is possible to divide scarlatinal cases into three categories from these observations: pupils or school children, pupil-contacts, and non-pupil-contacts.

An analysis of the serological types of haemolytic streptococci in these three classes showed that certain types predominated in the pupil cases. The types were relatively few in number and formed the main epidemic strains. The majority of new types came from those cases classed as "non-pupilcontacts" (families without children of school age). "Pupil-contact" cases were due to types present in both the other classes, but more frequently due to the types responsible for cases among school children (e.g. the epidemic types). The explanation probably lies in the fact that school children readily infect one another, whereas they are not so prone to infect members of families in which there are no playmates. The social intercourse of the parents of school children and such families would on the other hand lead to a certain degree of cross-infection.

Despite these type variations there was one main epidemic strain running through the whole community and affecting nearly all classes with equal intensity. The time it persisted was a variable factor, for later it was gradually replaced by another type. Thus type 1 accounted for a large proportion of the cases during the first part of the inquiry, but towards the latter end was almost completely replaced by type 4 . This agrees with the observations of Bradley (1938), who showed that at any particular time one type predominated but might become replaced by another.

The majority of cases which occurred in any one school or institution at a particular time was due to the same type of haemolytic streptococcus, irrespective of whether it was one of the epidemic types or not. This feature has also been illustrated by Bradley (1937). Furthermore, there was a tendency for such a type to persist in the school or institution for periods up to 4 months. In some cases a second type was introduced. It either rapidly disappeared after producing a few cases, or persisted at the expense of the disappearance of the original type. The resulting condition resembled the main epidemic, in which only one type predominated at any particular time. The explanation for this phenomenon is obscure, but it appears to depend to some extent upon the 
susceptibility of persons to the various types of haemolytic streptococci. If it can be shown conclusively that certain persons are more susceptible to one type than another, then the already attempted method of treating scarlatina by segregating patients with the same types appears logical and may be an important step towards the solution of the complication problem which confronts all fever hospital superintendents. It was shown in a previous paper (de Waal, 1940) that $61.5 \%$ of all scarlatinal complications were due to crossinfection with new types of haemolytic streptococci.

An attempt has been made to find what correlations there are between the types in scarlatina and other haemolytic streptococcal infections.

The literature on this subject has already reached impressive dimensions. Williams, Hussey \& Banzhaf (1924) and Stevens \& Dochez (1926) were among the first to draw attention to the fact that the haemolytic streptococci found in scarlatina were also responsible for other conditions like erysipelas, puerperal fever, tonsillitis, etc. This was confirmed partly or completely by the observations of Smith (1926, 1927), Maclachlan \& Mackie (1928), Ramsay (1935), Gordon et al. (1935), and more recently by those of Bradley (1937), Stebbins et al. (1937), Bailey (1939), Kodama et al. (1939), Neisser (1939), Diddle et al. (1940), and others. Much of the early work was carried out on haemolytic streptococci isolated from scarlatinal cases. At first it was believed (Moser \& v. Pirquet, 1902; Meyer, 1902; Rossiwall \& Schick, 1905) that haemolytic streptococci found in scarlatina formed a distinct serological group. Subsequently, however, this was proved to be incorrect (Dochez et al. 1919; Tunnicliff, 1920; Bliss, 1920; Gordon, 1921; and Williams et al. 1924). A great advance in the study of the types of haemolytic streptococci was made when Griffith (1926) introduced the slide-agglutination method of typing the organisms. In 1927 he produced evidence that $60 \%$ of all strains found in acute scarlatina belonged to one or more of the first four types in his classification (Griffith, 1927). That they are the types principally responsible for scarlatina in Britain has been amply borne out by the work of Gunn \& Griffith (1928), Green (1937) (who included type 5), Cooke \& Neisser (1937), and de Waal (1940). While this is true for Britain it does not follow that the same types predominate in other countries. Thus in Sydney, Australia, White, Rudd \& Ward (1939) have shown that types 1, 4, 11 and 17 account for $75 \%$ of all cases of scarlatina, while in New York Pauli \& Coburn (1937) pointed out the predominance of types 4,13 and 22 in streptococcal infections during 1935-36. Bailey (1939), among others, has also indicated the main epidemic types in America.

A further advance in the serological classification of streptococci was made when Lancefield (1928) demonstrated in these organisms the presence of a specific carbohydrate substance, and later developed a method of grouping these organisms, based on the precipitin test. A relationship between her 
system and Griffith's has been shown to exist, most of Griffith's types belonging to Lancefield's group A (Swift, Lancefield \& Goodner, 1935; Lancefield, 1933; Pauli \& Coburn, 1937). These two methods of classification at present form the basis" of nearly all epidemiological studies of haemolytic streptococcal infections from the serological point of view. In this inquiry Griffith's classification has been used almost exclusively.

It was found that puerperal fever differed markedly from scarlatina in that $44 \%$ of the haemolytic streptococci isolated could not be typed according to Griffith's slide agglutination method, either as the result of the granularity of the growth or their inability to react with specific sera. This observation is in accordance with the findings of Butler \& Hill (1940) in Australia. In scarlatina $81 \%$ of cases yielded haemolytic streptococci which could be typed (de Waal, 1940). ${ }^{*}$

The remaining puerperal fever types $(56 \%)$, with the exception of one (type 13), were the same as those found in other streptococcal infections. When a particular type occurred to any extent in scarlatina the same type was frequently found in puerperal fever.

In the case of erysipelas the findings were somewhat similar, but only in young persons. They appeared to contract the disease with the types prevalent in the general epidemic, whereas non-epidemic strains accounted for a high percentage of cases among older people.

Otitis media, tonsillitis, cases of haemolytic streptococcal infection, sent to an infectious diseases hospital and isolated in abservation cubicles, and cases of sore throats and "colds" occurring in medical students, were all shown to be due to the same epidemic types which caused scarlatina. The types of haemolytic streptococci were with few exceptions the same in the various conditions, and the relationship these types bore to one another during different periods was closely analogous.

A difference in the epidemic type was, however, observed in an area outside the main field of the present inquiry. In a village only 12 miles from Edinburgh the type most frequently encountered was 3, while in Edinburgh, at the time, type 4 was responsible for most cases of streptococcal infection. Furthermore, not a single type 3 was found in Edinburgh during this period of the inquiry. It is thus apparent that even short distances are sufficient to cause differences in the epidemic types of haemolytic streptococci. In this respect Keogh, Macdonald, Battle, Simmons \& Williams (1939) have shown that in a given area most of the cases of scarlatina are due to one main epidemic type and that this type may differ from place to place.

In Edinburgh itself certain variations in the main epidemic types were seen. For example, in a semi-closed community of nurses working in a general hospital type 20 was prominent, whereas at the time this type was of infrequent occurrence in other persons. In contrast, a number of nurses of an infectious 
diseases hospital were healthy carriers of the types prevalent at the time in scarlatina, puerperal fever and erysipelas. Cross-infection among the nurses was also observed. The highest carrier rate occurred among those nurses working in scarlet-fever wards. A similar carrier state existed in fever hospital medical officers and in a number of healthy medical students. In the latter class, however, non-epidemic types were of more frequent occurrence than in the medical officers and nurses.

A number of families who had members in hospital suffering from scarlatina were visited and throat swabs taken. In $37.5 \%$ of these, haemolytic streptococci were isolated from one or more persons. In half of these $(18.8 \%)$ the types could be correlated with those found in the scarlatinal patients.

A cursory investigation of the spread of haemolytic streptococci by fomites was made. In most cases the organisms remained viable on handkerchiefs, which had been taken from scarlatinal patients, for a period of 4 weeks, and in two instances for 7 weeks. After 15 weeks, however, they were all dead. Haemolytic streptococci were also isolated from toys and fruit handled by such patients.

Finally, it was shown that a person exposed daily to massive doses of haemolytic streptococci from patients developed a high degree of immunity to the organisms. He became a carrier of numerous types, but their persistence in the pharynx and nose was of short duration. They were more frequently encountered in the throat before exposure to infection and were almost invariably present in the nose after contact with cases. (This state of affairs in a mouth-breather might be the reverse.)

\section{SUMmary AND CONCLUSIONS}

1. The paper records the result of a study of the serological types of haemolytic streptococci in scarlatina, puerperal fever, erysipelas, ear infections, tonsillitis, erythemas, etc., and normal throats, and their epidemiological relationships.

2. Tables and charts are given showing statistical records of scarlatinal cases which occurred over a period of 16 months in Edinburgh, a city with a population of about half a million inhabitants. In all there were 2287 cases. Of these 2169 were treated in an infectious diseases hospital, and were thus readily accessible for investigation. 1364 of the cases were school children. The strains of haemolytic streptococci from 1664 of the hospital-treated cases were serologically examined.

3. During an epidemic of scarlatina certain schools practically escaped, but in these there was a proportionately greater number of cases the following year, as compared with those schools which had suffered heavily the previous season. 
4. Depending on the types of haemolytic streptococci isolated, scarlatina patients have been divided into three main categories: (1) pupils or school children, (2) "pupil-contacts" (families of pupils), and (3) "non-pupil-contacts" (families without children of school age). The types of haemolytic streptococci found in these three groups have been correlated. There was a similarity in the types found in pupils and "pupil-contacts", but not in those of pupils and "non-pupil-contacts". Those types obtained from "pupil-contacts" and "non-pupil-contacts" were related. These features have been discussed.

5. Certain types of haemolytic streptococci predominated in the pupil cases. These were for the most part the epidemic types. The non-epidemic types, sporadic in appearance, were found mostly in "non-pupil-contacts". "Pupil-contacts" occupied an intermediate position.

6. One main epidemic type ran through the three classes of patients. It was later replaced by another type.

7. The majority of cases of scarlatina which occurred in a school at a particular time were due to one type. It tended to persist despite the sporadic occurrence of other types. On occasions two types were present concurrently, but usually the one disappeared, and afterwards the other produced most of the cases.

8. The types of haemolytic streptococci in scarlatina, erysipelas, otitis media and mastoiditis, tonsillitis, and other streptococcal infections have been compared and the findings discussed. For the most part there was a correlation of types among all these conditions, and these types appeared to be responsible for a single epidemic of streptococcal infections.

9. The major epidemic types found simultaneously in the City of Edinburgh and in a small community, 12 miles distant, differed.

10. The types of haemolytic streptococci isolated from the throats of nurses in a general hospital bore little relationship to those isolated from medical officers and nurses in an infectious diseases hospital. The common epidemic types were present in the latter.

11. Correlations were shown to exist between the types of haemolytic streptococci in scarlatina patients, and those isolated from various members of their families, in $50 \%$ of the occasions in which the organisms were found.

12. The rapid change in the types occurring in the nasopharynx and the problem of immunity have been investigated and discussed in the case of a person exposed to massive infections with haemolytic streptococci.

13. Haemolytic streptococci on the handkerchiefs of scarlatina patients were viable after 4 weeks in most cases and after 7 weeks in two cases. After 15 weeks they were all dead.

14. Haemolytic streptococci were isolated from toys and fruit taken from scarlatina patients. 
This work was carried out with the aid of the Davidson Research Fellowship and certain grants from the Moray Fund. I wish to thank the Medical Officer of Health for Edinburgh and the staff of his Department, and Dr A. Joe of the City Fever Hospital for the facilities they offered me in rendering this work possible. I am indebted to Dr F. Griffith who supplied me with his type strains and specific sera, and to Prof. T. J. Mackie for his valuable advice and the interest he has shown in the inquiry.

\section{REFERENCES}

BaILEY, J. H. (1939). Types of hemolytic streptococci found in scarlet fever patients and in throats of grammar-school children. Amer. J. Hyg. Sect. B, 29, 107-18.

Burss, W. P. (1920). A biological study of hemolytic streptococei from throats of patients suffering from scarlet fever; a preliminary report. Johns Hopk. Hosp. Bull. 31, 173-6.

Bradiery, W. H. (1937). Epidemiology of streptococcal infections. Guy's Hosp. Rep. 87, $372-90$.

(1938). Spread of streptococcal disease. Brit. med. J. 2, 733-8.

BuTLER, H. M. \& HII, A. M. (1940). Haemolytic streptococcal infections following childbirth and abortion: determination of virulence of group A strains. Med. J. Aust. 1, 222-8.

Сооке, M. J. \& NeISSER, H. (1937). Serological types of Streptococcus pyogenes in scarlet fever. Ann. Rep. Lond. County Coun. 4, pt. 3, $104-7$.

Diddle, A. W., Trusseld, R. E. \& Plass, E. D. (1940). Scarlet fever in obstetrics; a report of an epidemic. Amer. J. Obstet. Oymec. 39, 608-17.

Dochez, A. R., Avery, O. T. \& LANCEFTuLd, R. C. (1919). Studies on the biology of streptococcus. I. Antigenic relationships between strains of Streptococcus haemolyticus. $J$. exp. Med. 30, 179-213.

GoRDoN, M. H. (1921). A serological study of haemolytic streptococi. Brit. med. J. 1, $632-6$.

Gordon, J. E., Badger, G. F., Darling, G. B. \& Schooten, S. S. (1935). Reaction of familial contacts to scarlet fever infection. Amer. J. Publ. Hlth, 25, 531-44.

GREEN, C. A. (1937). Serological types of haemolytic streptococci in an epidemic of scarlatina. J. Hyg., Camb., 37, 318-31.

GrTFTTH, F. (1926). Types of haemolytic streptococci in relation to scarlet fever. J. Hyg., Camb., 25, 385-97.

- (1927). Types of haemolytic streptococci in relation to scarlet fever. J. Hyg., Camb., 26, 363-73.

- (1934). The serological classification of Streptococcus pyogenes. J. Hyg., Camb., 34, $542-84$.

GUNN, W. \& GRIFTTH, F. (1928). Bacteriological and clinical study of 100 cases of scarlet fever. J. Hyg., Camb., 28, 250-66.

Keogh, E. V., Macdonald, I., Battle, J., Simmons, R. T. \& Puckey, M. C. (1939). Serological types of streptococci associated with scarlet fever in Adelaide. Med. J. Aust. 1, $792-3$.

Keogh, E. V., Macdonald, I., Batple, J., Simmons, R. T. \& Whliams, S. (1939). Some factors influencing the spread of scarlet fever in an institution. J. Hyg., Camb., 39, 664-73.

Kodama, T., Ozaki, M., Nisiyama, S., Igarasi, J., Tuko, Y. \& Kawamura, H. (1939). Serological grouping and typing of haemolytic streptococci isolated in Tokyo. Kitasato Arch. 16, 110-33. 
Luxcamprad, R. C. (1928). Antigenic complex of Streptococcus hemolyticus, etc. J. exp. Med. 47, 91-103.

(1933). Serological differentiation of human and other groups of hemolytic streptococci. J. exp. Med. 57, 571-95.

Maclachlak, D. G. S. \& MaCkIE, T. J. (1928). Serological study of haemolytic streptococci associated with scarlatina. J. Hyg., Camb., 27, 225-47.

MEYRR, F. (1902). Dtsch. med. Wschr. 28, 751.

Moser, M. \& v. PIrquet (1902). Wien. Klin. W schr. 15, 1086.

Nessser, H. (1939). Serological typing of Streptococcus pyogenes and its applications to certain infective conditions. J. Path. Bact. 48, 55-66.

Padi, R. H. \& Coburn, A. F. (1937). Studies on serological typing of Streptococcus hemolyticus. J. exp. Med. 65, 595-612.

Ramsay, G. H. (1935). Scarlet fever and streptococcal infection. Trans. 4th Ann. Meet. So. Branch Amer. Publ. Hlth Ass. (St Louis), Nov. pp. 24-31.

Rosstwatl, E. \& SCHTOK, B. (1905). Ueber spezifische agglutination von streptokokken aus scharlachanginen und extrabukkalem primäraffekt. Wien. klin. Wschr. 18, 3-7.

Sмrтн, J. (1926). The seralogical classification of haemolytic streptococci obtained from cases of scarlet fever. J. Hyg., Camb., 25, 165-75.

(1927). Further studies on the serological classification of haemolytic streptococci. J. Hyg., Camb., 26, 420-33.

Strebins, E. L., InGraham, H. S. \& REED, E. A. (1937). Milk-borne streptococcic infections. Amer. J. Publ. Hlth, 27, 1259-66.

STEvens, F. A. \& Dochez, A. R. (1926). Occurrence of throat infections with Streptococcus scarlatinae without a rash. J. Amer. med. Ass. 86, 1110-12.

SWITT, H. F., LANCEFTELD, R. C. \& GOODNER, K. (1935). Serological classification of hemolytic streptococci in relation to epidemiologic problems. Amer. J. med. Sci. 190, 445-53.

TunNichIF, Ruti (1920). Specific nature of the hemolytic streptococcus of scarlet fever. J. Amer. med. Ass. 74, 1386-8.

DE WAAL, H. L. (1940). Serological types of haemolytic streptococci in relation to the epidemiology of scarlet fever and its complications. J. Hyg., Camb., 40, 172-203.

WHITE, C., RUDD, G. V. \& WARD, H. K. (1939). Serological types of haemolytic streptococci causing scarlet fever in Sydney. Med. J. Aust. 1, 96-100.

Whulams, A. W., Hussey, H. D. \& BANZHAF, E. J. (1924). Culture filtrates of hemolytic streptococci from scarlet fever: intracutaneous reactions in test animals. Proc. Soc. exp. Biol., N.Y., 21, 291-3.

(MS. received for publication 7. XII. 40-Ed.) 